\title{
Bulaşıcı Hastalıklara İlişkin Tedbirlere Aykırı Davranma Suçu (TCK md 195)
}

\author{
Recep Kahraman* ${ }^{*}$
}

Öz

Korona virüsü gibi bulaşııı hastalıklar, toplumda salgınlara, sosyal ve ekonomik zararlara neden olabilen hastalıklardır. Bu sebeple bulaşıcı hastalıklarla mücadelede kamu sağı̆ğııın korunmasına ilişkin alınan tedbirler önem arz etmektedir. Bulaşıc hastalıklarla mücadele ederek kamu sağlığııın korunması amacıyla, yetkili makamlar tarafindan alınan karantina tedbirlerine aykırı hareket edilmesi 5237 sayılı Kanun'da düzenlenmiştir. Madde 195'de yer alan suç tipinde, bulaşıı hastalığa yakalanan ya da bulaşıcı hastalıktan dolayı ölmüş olan kişinin bulunduğu yere ilişkin olarak karantina önlemlerinin yetkili makamlar tarafindan alınmış olması gerekir. Bulaşıcı hastalığın türü, yayılma şekli veya kapsadığı alan suçun unsurlarının oluşumu için önemli değildir. Karantina tedbirleri, uygun araçlarla topluma duyurulmalıdır. Suçun tamamlanması için hastalı̆̆ın başkalarına bulaştrııması ya da birilerinin hastalıktan dolayı zarar görmüş olması gerekli değildir. Cezalandırma faaliyetine dahil edilmesi ihtiyacı hasıl olan hareket tipi, bulaşıcı hastalıkla alakalı tedbirlere uymama şeklinde ortaya çıkmaktadır. Tedbirlere aykıı davranmanın aktif ya da pasif hareketlerle gerçekleştirilmesi mümkündür. Ancak hareketlerin, mevcut bulaşıcı hastalığın yayılmasını engellemek amacıyla alınan tedbirleri ihlal etmeye elverişli olması gerekir. Yetkili makamlar tarafindan alınmış olan tedbirlere aykırı hareket edilmesiyle birlikte suç tamamlanmış olur. Madde 195'de yer alan suç tipi şikayete tabi olmayıp yaptrım olarak hapis cezası öngörülmüştür.

\author{
Anahtar Kelimeler \\ Korona virüsü, Bulaşıcı hastalık, Kamu sağlığı, Karantina önlemleri, Tedbirlerin ihlal edilmesi
}

The Crime of Violating the Measures Related to Infectious Diseases (TCC Art 195)

\begin{abstract}
Infectious diseases such as COVID-19 can cause epidemics in a community, while also causing social and economic damages. For this reason, measures taken toward protecting public health are important in the fight against infectious diseases. One of these measures for combating infectious diseases is its regulation. According to the regulation by the law no. 5237, it is criminal to act against the quarantine measures instructed by the competent authorities. According to the type of crime included in the Article 195, the quarantine measures must be taken up by the competent authorities in relation to the location of the person who has been confirmed to be infected or had died due to an infectious disease. The type of infectious disease, its spread, or the area it covers are not important in relation to the occurrence of elements of crime. Quarantine measures should be announced to the public through appropriate means. Here, crime is not necessarily defined as the disease transmission to others or damaged caused to someone. The type of action that needs to be included in the punishment activity involves non-compliance with the infectious disease-related measures. It is possible to act against measures via an active or passive action. However, these actions must be comparable to those of violating the measures instructed to prevent the spread of the existing infectious disease. The crime is completed by acting against the measures taken by the competent authorities. The investigation and prosecution of the crime in the Article 195 is not subject to complaints, and imprisonment is accepted as a punishment.
\end{abstract}

\section{Keywords}

Corona virus, Infectious disease, Public health, Quarantine measures, Violation of measures.

* Sorumlu Yazar: Recep Kahraman (Dr. Öğr. Üyesi), Necmettin Erbakan Üniversitesi, Siyasal Bilgiler Fakültesi, Maliye Anabilim Dalı, Konya, Türkiye. E-posta: recepkhrmn@gmail.com ORCID: 0000-0002-0991-9692

Attf: Kahraman R, "Bulaşıcı Hastalıklara Ilişsin Tedbirlere Aykırı Davranma Suçu (TCK md 195)" (2020) 78(2) İstanbul Hukuk Mecmuası 737. https://doi.org/10.26650/mecmua.2020.78.2.0016 


\section{Extended Summary}

The infectious disease called Covid-19, which emerged in China in 2020, spread rapidly and affected several people across the world. Although the molecular mechanisms beneath the corona virus's exact human-to-human transmission pathway remains unresolved, the transmission principle of respiratory diseases in general is similar. Respiratory diseases are spread by droplet scattering. In this type of spreading, when a sick person coughs or sneezes, the people around him get exposed to the microbe. The current pandemic was declared by the World Health Organization, who reported that the speed, severity of the corona virus, and the failure of the authorities to take the necessary measures have raised alarms. Pandemic is the term conferred to an infectious disease that has threatened a large number of people simultaneously across the world.

Organisms that cause infectious disease can be viruses, bacteria, or fungi. These diseases are defined as infectious diseases owing to their ability to pass from one individual to another or from one species to another. With the fast pace at which people are currently moving at the global level, infectious diseases are spreading at unprecedented rates. Health systems are facing difficulties in responding to this situation. Therefore, it is necessary to identify infectious diseases quickly and to establish appropriate communication among countries to prevent its further spread. The development of effective communication and cooperation is also possible thanks to the international common will in such situations.

Protection of the public health is among the important issues for all societies. Since the protection of public health by combating infectious diseases is among the obligations of the public administration, states have brought some legal regulations toward protecting the health of individuals who contribute to keeping the society safe from attacks or dangers. A number of measures have been taken to prevent this disease from emerging in new regions or from spreading further. The administrative authorities possess the power to enforce sanctions in order to make it obligatory for individuals to comply with the measures instructed, and the violation of these measures is also sanctioned in the penal laws. In order to ensure that these measures are effective in preventing the spread of infectious disease, the act of violating these measures has been regulated as a crime of violating the measures related to infectious diseases as per the Article 195 of the Turkish Penal Code No. 5237. Any person who fails to comply with quarantine measures, imposed by the authorities on account of there being a person infected with a contagious disease or having died from such, shall be sentenced to a penalty of imprisonment for a term of two months to one year. The legislator can decide to quarantine the place where the person who was infected or died due to illness as a step to combat this infectious disease with the aim to prevent the actions of people who endanger the public health by violating the measures taken under the quarantine period. 
Although it is a crime to act against the measures instructed by the competent authorities in order to prevent the spread of the disease, there are some structural deficiencies in the related crime type. This unclear situation damages the purpose of protecting the public health via prevention of the spread of the disease. In addition, deficiencies and contradictions in the relevant crime type may lead to unlawful punishments. For this reason, this article intends to contribute to the fight against the disease by the competent authorities by suggesting the relevant crime type, through revealing the missing and contradictory points in order for the crime type in the Article 195 to become effective.

The legal value protected by the crime of violating the measures related to infectious diseases is the protection of public health and public order. In addition, those who increase the outbreak intensity by not following the precautions also harm the freedom of the individual, as the people in the community restrict freedom of movement. The offender of the crime can be anyone, since a special feature is not required for the offender in the crime of violating the measures related to infectious diseases. Since the crime is not committed against certain people, there is a possibility that everyone living in that community will be harmed due to the violations of the measures, threatening the health of the public. For this reason, the victims of the crime are considered as the people who make up the society and who want to be protected by the measures instructed.

In the crime of violating the measures related to infectious diseases, there are some prerequisites that are included in the material element of the crime. For instance, the disease should primarily be an existing infectious disease. In addition, there must be someone who has contagious disease or had died due to the existing disease in that location. In case the virus has not been transmitted to anyone yet, quarantine measures could be taken to prevent the disease from emerging or spreading to anyone in the country. In case of violation of these measures, no responsibility can be imposed under the Article 195. For this reason, the condition of transmission of the disease should be removed from the law. Moreover, quarantine measures must be practiced by the competent authorities to prevent the spread of the infectious disease at a location where someone has been reported positive for the disease or had died from it. As stated in the law, the condition that the act constitutes a crime is not to comply with the measures taken for the quarantine of the place where a person who has a contagious disease or dies is located. From this perspective, since the scope is rather narrowly regulated, the law cannot meet the legal needs arising from the current epidemic. When it comes to covering the cases related to the virus across the country, measures should be applied throughout the country. In this case, the location of the person who has the disease should be interpreted relative to the entire country. Within the scope of the above explanations, the criminal as per the Article 195 should 
be reorganized as a person who violates the measures instructed by the competent authorities in order to prevent the emergence or spread of infectious diseases.

The crime of violating infectious disease measures is aimed at preventing the danger posed by the disease itself. Violation of these measures being supervised by the competent authorities directly endangers the public health. Therefore, violation of these measures indicate commitment of a crime. The violation is not sought to cause harm or danger. It is possible that the action contrary to the measures taken by the competent authorities may be active or passive. For instance, entering or exiting the quarantine zone is subject to the permission condition. Entering or exiting without permission is considered as an active action. Although people entering the country have to wait in certain places for a certain period of time (self-isolation), not going to specified places is considered as a passive action. 


\section{Bulaşıcı Hastalıklara İlişkin Tedbirlere Aykırı Davranma Suçu}

\section{Giriş}

2020 y1lında ortaya çıkan ve hemen hemen tüm ülkeleri etkileyen COVID-19 adlı virüs, insanlara bulaşan tehlikeli bir hastalığa yol açması, devamlı ve kolayca yayılması kriterlerini sağlaması sebebiyle salgın olarak kabul edilmektedir.

COVID-19 virüsü gibi bulaşıcı hastalıkların ortaya çıkmasını ya da yayılmasını önlemek için yetkili makamlar, idari tedbirler almaktadırlar. Bireylerin, toplum sağlığını gözetme ve koruma yükümlülüğü bulunduğundan, idari makamlar tarafından belirlenen tedbir ve talimatlara uymaları gerekmektedir. ${ }^{1}$

Alınan tedbirlere aykırı davranılması kamu sağlığına zarar verdiğinden, yetkili makamlar tarafından alınan tedbirleri ihlal eden kişinin hareketinin ceza hukuku bakımından sonuçları bulunmaktadır. Caydırıcılığın etkili olması amacıyla ceza hukukunun uygun rolünün dikkatle değerlendirmesi gerekir. $\mathrm{Bu}$ amaçla ceza kanunlarında, bulaşıcı hastalığın ortaya çıkmasını veya yayılmasını engellemek amacıyla belli suç tipleri oluşturulmuştur. Alınan tedbirlere uyulmaması halinde kişilerin cezai sorumluluklarına gidilebilmektedir.

Yetkili makamlar tarafindan alınan, uyulması zorunlu idari tedbirlere aykırı davranılması hali, Bulaşıcı Hastalıklara İlişkin Tedbirlere Aykırı Davranma Suçu adıyla 5237 sayılı Türk Ceza Kanunu md 195'de yaptırıma bağlanmıştır.

\section{Kanuni Düzenleme}

Kamu sağlı̆̆ının korunması tüm toplumlar için önemli ve tedbir alınması gereken konular arasındadır. ${ }^{2}$ Bu bakımdan Devletler, toplumu oluşturan bireylerin sağlığını, saldırı veya tehlikelerden korumak amacıyla birtakım kanuni düzenlemeler getirmiş ve kendisini de bu konuda yükümlü kılmıştır. ${ }^{3}$

5237 sayılı Türk Ceza Kanunu md 1'e göre kamu sağlığının korunması, kanunun amaçları arasında yer almaktadır. Bu amacı gerçekleştirmek ve bulaşıcı hastalıklarla

Lawrence O Gostin and Benjamin E Berkman, "Pandemic Influenza: Ethics, Law, and the Public's Health" (2007) ALR 121,150 .

David P Fidler, “Globalization, International Law, and Emerging Infectious Diseases” (1996) (2) EID 77, 80; Bulaşıcı hastalıkla mücadele konusunda ulusal mevzuatların yanında uluslararası hukukun da etkin şekilde kullanılması gerekir. Ancak hastalığın ülkelerarası yayılmasının engellenmesi amacıyla tedbirler alınmış olmasına karşın ihlal durumunda yaptırımın uygulanmasını gerektiren uluslararası araçlar bulunmamaktadır. Bu nedenle bulaşıcı hastalıkla mücadele genellikle ulusal düzeyde yürütülmektedir. Hastalığın bulaşıcı olmasından dolayı mücadelenin ulusal düzeyde kalması, etkinliğinin zayıflamasına neden olmaktadır.

3 Özlem Yenerer Çakmut, "Bulaşıcı Hastalıklara İlişkin Tedbirlere Aykırı Davranma Suçu” Feridun Yenisey'e Armăgan Cilt I, (Beta 2014) 543, 545; 1982 Anayasası md 56'ya göre Devlet, herkesin hayatını, beden ve ruh sağlığı içinde sürdürmesini sağlamakla yükümlüdür. Benzer şekilde 1593 sayılı Umumi Hıfzıssıhha Kanunu md 1'e göre memleketin sıhhi şartlarını ıslah ve milletin sıhhatine zarar veren bütün hastalıklar veya sair muzır amillerle mücadele etmek ve müstakbel neslin sıhhatli olarak yetişmesini temin ve halkı tıbbi ve içtimai muavenete mazhar eylemek umumi Devlet hizmetlerindendir. İbrahim Şahbaz, Açıklamalı ve İçtihatlı Türk Ceza Kanunu Cilt II (Yetkin 2016) 2263. 
mücadele etmek adına yetkili idari makamlar tarafından alınmış olan önlemlerin ihlal edilmesi hali 5237 sayılı Kanun'un Kamunun Sağlığına İlişkin Suçlar başlı̆̆ını taşıyan üçüncü bölümünde md 195'de yer alan Bulaşıcı Hastalıklara İlişkin Tedbirlere Aykırı Davranma Suçunu oluşturmaktadır.

Madde 195 'de yer alan suç tipi, salgınla mücadele için koruyucu bir mekanizma olarak karşımıza çıkmaktadır": "Bulaşıcı hastalıklardan birine yakalanmış veya bu hastalıklardan ölmüş kimsenin bulunduğu yerin karantina altına alınmasına dair yetkili makamlarca alınan tedbirlere uymayan kişi cezalandırılır.” Kanun koyucu, bulaşıcı hastalıkla mücadele etmek adına hastalığa yakalanmış ya da hastalık dolayısıyla ölmüş kişinin bulunduğu yerde karantina tedbirlerinin uygulanmasına karar vermiş ve alınan tedbirlere uymayarak kamunun sağlığını tehlikeye düşüren kişilerin hareketlerini engellemeyi amaçlamıştır. ${ }^{5}$

Bulaşıcı hastalıklara ilişkin tedbirlere aykırı davranma suçuna benzer düzenleme 765 say1lı Türk Ceza Kanunu md 263'te yer almaktayd1. "Kolera ve sair bulaşık hastalılardan musab veya vefiyat zuhur eden ev ve sair mahallerin kordon altına alınmasına dair Hükümetçe verilen emirlere ve yapılan icraata fiillen mümanaat edenler hareketlerinin derecesine göre bir aydan bir seneye kadar hapsolunur." Madde 263'te yer alan suçun özel olarak bir adı olmamasına rağmen hüküm içeriğinden açıkça anlaşılmaktadır ki failin hareketi, bulaşıcı hastalıklara karşı alınan tedbirlere engel olma suçunu oluşturmaktadır. ${ }^{6}$

Bulaşıcı hastalıklara ilişkin tedbirlere aykırı davranma hali, 765 sayılı Kanun'da, Hükümete Karşı Şiddet ve Mukavemet ve Kanunlara Muhalefet başlı̆̆ 263 'te düzenlenmişti. 5237 sayılı Kanun'da ise Kamunun Sağlı̆̆ına Karşı Suçlar başlı̆̆1 altında md 195'de düzenlenmiştir. 765 sayılı Kanun md 263 'te yer alan suç tipi, 5237 sayılı Kanun md 195'de yer alan suç tipine göre oldukça dar kapsamlı düzenlenmişti. Madde 263'e göre bulaşıcı hastalığın görüldüğü ev ve sair mahallerin kordon altına alınmasına dair alınan tedbirlerin ihlali suç sayılmasına rağmen, madde 195'e göre bulaşıc hastalığa yakalanmış ya da ölmüş kimsenin bulunduğu yerin karantina altına alınmasına dair alınan tedbirlerin ihlali suç sayılmaktadır. 765 sayılı Kanun'da tedbirler, ev ya da diğer mekanların kordon altına alınmasına yönelik iken, 5237 sayılı Kanun'da karantina uygulamasına yönelik tedbirler söz konusu

\footnotetext{
Süheyl Donay, Türk Ceza Kanunu Şerhi (Beta 2007) 290.

Şahbaz (n 3) 2263; Madde 195'de yer alan bulaşıcı hastalıklara ilişkin tedbirlere aykırı davranma suçunun dayanağı, 1982 Anayasası md 56, 1593 sayılı Umumi Hıfzıssıhha Kanunu md 1 ve 5237 sayılı Türk Ceza Kanunu md 1 olarak gösterilebilir. Abdullah Pulat Gözübüyük, Türk Ceza Kanunu Açıklaması, Cilt III (Sevinç 1970) 338.

Çakmut (n 3) 544; 5237 sayılı Kanun ile 765 sayılı Kanun karşılaştırıldığında görülmektedir ki 5237 sayılı Kanun'da suçun sözel ifadesi, yer aldığı başlık ve sistematik yapısı tamamen değiştirilmiştir. Bu nedenle 5237 sayılı Kanun md 195'de yer alan suçun yorumlanabilmesinde 765 sayılı Kanun md 263'e ilişkin hükmün, doktrin ve yargı kararlarının kullanılabilmesi kısmen mümkün olmamaktadır. Bu durum doktrinde ilerleme ve içtihatta kesintisizlik ilkelerine kısmen zarar vermektedir. Zeki Hafızoğulları ve Muharrem Özen, Türk Ceza Hukuku Özel Hükümler Topluma Karşıl Suçlar (USA 2017) 127.
} 
olmaktadır. ${ }^{8}$ Hangi hastalıkların suçun kapsamında olduğu konusunda her iki kanuni düzenlemede ifadelerde farklılık olsa da içerikleri aynıdır. 765 sayılı Kanun'da kolera ve sair bulaşıcı hastalık, 5237 sayılı Kanun'da ise hastalığın ne olduğuna yer verilmeksizin bulaşıcı hastalık ifadesi kullanılmıştır. 765 sayılı Kanun' da hükümetçe verilen emirler ve yapılan icraata aykırılık suçun unsuru olmasına karş11ı, 5237 sayılı Kanun'da bu husus yetkili makamlarca alınan tedbirlere aykırılık olarak ifade edilerek tipe uygun hareket daha geniş tutulmuştur. ${ }^{10} 765$ sayılı Kanun' da tipik hareket, fiilen mümanaat etmek diğer ifadeyle fiilen karşı koymaktır. 5237 sayılı Kanun'da ise tedbirlere uyulmaması yeterli kabul edilmiş̧ir. Maddi nitelikte olmayan, fiilen bir karşı çıkmayı içermeyen hareketler de suçun oluşmasına neden olabilir. ${ }^{11}$

5237 sayılı Kanun md 195 'e göre, hastalığın bulaştığı kişinin ya da hastalıktan dolayı ölmüş olan kişinin bulunduğu yere ilişkin alınan karantina tedbirlerinin ihlal edilmesine bağlı olarak suç oluşmaktadır. ${ }^{12}$ Hastalık henüz bir kişiye bulaşmamış ya da ölümüne neden olmamışsa alınan tedbirlerin ihlali suça neden olmayacağından suç tipi, bulaşıcı hastalığın ortaya çıkmasının engellenmesi için değil yayılmasının engellenmesi amacıyla oluşturulmuştur. Henüz o bölgede hastalık kimseye bulaşmadığında, bulaşmasının engellenmesi amacıyla karantina önlemleri alındığı takdirde, bu tedbirlere uyulmaması suç oluşturmayacağından ilgili suç tipi bulaşıc1 hastalıkla mücadele konusunda yetersiz kalmaktadır. Karantinanın işlevi hastalığın ortaya çıkması veya yayılmasının engellenmesi olduğuna göre karantina alanının hastalığa yakalanan ya da ölen kişinin bulunduğu yer ile sınırlandırılması hükmün konuluş amacına aykırı olmaktadır. Özellikle COVID-19 virüsünün Ülkemizde henüz hastalık olarak bulunmadığ 1 durumda hastalığın ülke içerisinde kimseye bulaşmaması için karantina önlemleri alınabilirdi. Bu tedbirlerin ihlali halinde ise md 195 gereğince sorumluluğa gidilemezdi. Bu nedenle suç tipinden hastalığın bir kişiye bulaşması koşulunun çıkartılması gerekir.

Madde 195 'de yer alan suç tipi, ceza hukukunun caydırıcı gücü kullanılarak, bulaşıcı hastalıkla mücadele edilmesi adına şu şekilde yeniden tanımlanmalıdır. "Bulaşıcı hastalıkların ortaya çıkmasını veya yayılmasını engellemek amacıyla karantina altına almaya yönelik yetkili makamlar tarafindan alınan tedbirlere uymayan kişi altı aydan iki yıla kadar hapis cezası ile cezalandırllır."

\footnotetext{
Osman Yaşar, Hasan Tahsin Gökcan ve Mustafa Artuç, Yorumlu ve Uygulamalı Türk Ceza Kanunu Cilt IV (Adalet 2011 ) 603. Çakmut (n 3) 544.

10 Zeynel Temel Kangal, "Bulaşııı Hastalıklara İlişkin Tedbirlere Aykırı Davranma Suçu” Özel Ceza Hukuku CILT V (Onikilevha 2019) 433, 435.

11 ibid 442.

12 Donay (n 4) 290.
} 


\section{Suçun Maddi Unsuru}

\section{A. Genel Açıklamalar}

Bulaşıcı hastalıklara ilişkin tedbirlere aykırı davranma suçunda maddi unsur incelemesi belli bir sıraya göre yapılmıştır. Öncelikle suç tipinde yer alan ve maddi unsura dahil olan yetkili makamlar tarafindan alınan tedbirlerin nitelikleri incelenmiştir. Daha sonra suçun faili, mağduru ve suçun maddi ve hukuki konusu ve son olarak suç teşkil eden fiil incelenmiştir.

\section{B. Yetkili Makamlar Tarafından Alınan Tedbirlerin Nitelikleri}

5237 sayılı Kanun md 195'de yer alan bulaşıcı hastalıklara ilişkin tedbirlere aykırı davranma suçunda, hastalı̆̆ın ortaya çıkması halinde yetkili makamlarca alınacak tedbirlere uyulmaması suç olarak tanımlanmıştır. ${ }^{13}$ İlgili suçta, yetkili makamlar tarafindan alınan tedbirlerin birtakım nitelikleri bulunmaktadır. ${ }^{14}$ Suç tipinde yer alan niteliklerin somut olayda bulunmaması halinde maddi unsur eksikliğinden dolayı suç oluşmaz. ${ }^{15}$

Öncelikli olarak mevcut bir bulaşıcı hastalık olmalıdır. ${ }^{16}$ Bulaşıcı hastalığın türü, yayılma şekli veya kapsadığı alan suçun unsurlarının oluşumu için önemli değildir. ${ }^{17}$

İkinci olarak bulaşıcı hastalığa yakalanmış ya da mevcut hastalı̆̆a bağlı olarak ölmüş bir kimse olmalıdır. ${ }^{18}$ Bulaşıcı hastalıklara ilişkin tedbirlere aykırı davranma suçunda, karantina tedbirlerinin alınabilmesi için hastalığı üreten ya da taşıyan bir hayvan ya da nesnenin tespit edilmiş olması yeterli olmaz. Hastalığa bağlı olarak bir kişinin hastalanmış ya da ölmüş olması gerekir. En az bir kişiye bulaşmış olması yeterli olup toplumun belli bir kesiminin hastalıktan etkilenmiş olması gerekli değildir. ${ }^{19}$

\footnotetext{
13 Hafızoğulları ve Özen (n 7) 128; Hasan Gerçeker, Yorumlu ve Uygulamalı Türk Ceza Kanunu Cilt II (Seçkin 2020) 1836; Yaşar, Gökcan ve Artuç (n 8) 6036; Ali Parlar ve Muzaffer Hatipoğlu, Türk Ceza Kanunu Yorumu (Seçkin 2008) 2930; Sami Gören, Açılamalı - İçtihatlı Türk Ceza Kanunu (2012) 1132; İsmail Malkoç, Açıklamalı Türk Ceza Kanunu Cilt III (2013) 3232; Çetin Arslan ve Bahattin Azizağaoğlu, Yeni Türk Ceza Kanunu Şerhi (Asil 2004) 818; Donay (n 4) 290; Şahbaz (n 3) 2263; Kangal (n 10) 21; Cakmut (n 3) 544; Vural Savaș ve Sadık Mollamahmutoğlu, Türk Ceza Kanunu Yorumu Cilt II (Seçkin 1999) 2392; R Murat Önok, "Bulaşıcı Hastalıklara İlişkin Tedbirlere Aykırı Davranma Suçu (TCK md 195)” (2020) 9 (17) Anayasa Hukuku Dergisi 147, 148.

14 Arslan ve Azizağaoğlu (n 13) 818.

15 Malkoç (n 13) 3232.

16 Gözübüyük (n 6) 339; Bulaşıcı hastalık ifadesi, Devletin mücadele etmesi gereken hastalıklardan birisi olarak 1593 sayılı Umumi Hıfzıssıhha Kanunu md 29'da yer almaktadır. Bulașıcı Hastalıklar Sürveyans ve Kontrol Esasları Yönetmeliğ md 4/1-c hükmüne göre bulaşıcı hastalık; enfekte olmuş bir kişi ile doğrudan temas yoluyla veya bir vektör, hayvan, ürün veya çevreye maruz kalma gibi dolaylı yollardan veya bulașıcı madde ile kirlenmiș olan sıvı alıșveriși yolu ile insandan insana bulaşan, bir mikroorganizma veya onun toksik ürünlerine bağlı olarak ortaya çıkan hastalıktır. Yönetmeliğin Ek-1 Sayılı Bildirime Esas Bulașıcı Hastalıklar Listesi'nde ise hangi bulaşıı hastalıkların bildirime esas bulașıcı hastalık olarak sayıldığı listelenmiştir. Bulaşıcı hastalığa neden olan organizmalar, virüsler, bakteriler veya mantarlar olabilir. Bu hastalıklar, bir bireyden diğerine veya bir türden diğerine geçebilme özelliklerinden dolayı bulașıcı hastalık olarak tanımlanırlar. Bu bağlamda COVID-19 virüsü de solunum yolu ile bulaşan hastalıklardan biri olup, ilgili listede 50'nci sırada yer alan bir bulaşıcı hastalık olarak karşımıza çıkmaktadır.

17 Özütürk, Nejat, Türk Ceza Kanunu Şerhi ve Açılklaması Cilt I (Filiz 1970) 1020.

18 Tuğba Bayzit COVID-19 Salgınının Hukuki Boyutu (Editör Muhammet Özekes) (Onikilevha 2020) 865, 876.

19 Kangal (n 10) 438.
} 
Üçüncü olarak hastalığa yakalanan ya da hastalıktan dolayı ölmüş bulunan kimsenin bulunduğu yere ilişkin olarak, bulaşıcı hastalığın yayılmasını önlemek amacıyla idari makamlar tarafindan karantina tedbirlerinin alınması gerekir. ${ }^{20}$ Karantina tedbirleri, kişiye değil hastalığın bulunduğu yere ilişkin olarak alınmaktadır. ${ }^{21}$

Karantinanın sözlükteki tanımı şu şekilde yapılmaktadır: "Karantina, bulaşıcı bir hastalığın yaygın olduğu kaynaktan gelen kişilerin geçici olarak bir yerde tutulup gözlemlenmesi biçiminde uygulanan tedbirdir."22 Karantina, bulaşıc1 bir hastalığa maruz kalmış kişilerin hareket kısıtlaması da dahil olmak üzere, hasta olup olmadıkları veya başkaları için risk oluşturmadıkları belirlenene kadar zorunlu olarak birey aktivitelerinin kısıtlanmasıdır. ${ }^{23}$ Genel olarak bulaşıcı hastalığın yayılmasını engelleme amacını taşıyan bir takım kısıtlamalar için kullanılan ifadedir. ${ }^{24}$

Madde 195'de yer alan karantina altına alınmasına yönelik tedbirler ifadesi sadece karantina bölgesine giriş - çıkışların engellenmesine yönelik tedbirler olarak anlaşılmamalıdır. Karantina, o yerdeki insan hareketinin sınırlandırılmasını ifade eden genel bir terimdir. ${ }^{25} \mathrm{Bu}$ sınırlandırmanın türü ne olursa olsun her biri için karantina ifadesi kullanılmaktadır.

Madde 195 'de yer alan suç tipinde karantina ifadesinin kullanılması, kanun koyucunun bulaşıcı hastalıkla mücadele adına her eylemi cezalandırma yolunu tercih etmediğini göstermektedir. Ultima ratio ilkesine uygun olarak karantina altına alma amacıyla alınan tedbirlere uymamak yaptırıma bağlanmaktadır. Ultima ratio ilkesine göre ceza hukukunun araçlarına en son çare olarak başvurulmalıdır. Nitekim kanun koyucu karantina dışında alınan tedbirlerin ihlalini suç olarak kabul etmemektedir. Bulaşıcı hastalığın ortaya çıkmasını veya yayılmasını engellemek adına, örneğin maske takma ya da sosyal mesafe kuralına uyma zorunluluğunun ihlali halinde bulaşıcı hastalıklara iliş̧kin tedbirlere aykırı davranma suçu oluşmaz.

\footnotetext{
Gerçeker (n 13) 1837.

Önok (n 13) 163.

John M Last, A Dictionary of Epidemolgy (Oxford University Press 2001) 100.

Gostin and Berkman (n 1) 147.

4 Eugenia Tognotti, "Lessons from the History of Quarantine, from Plague to Influenza A" (2013) 19 (2) EID 254, 258; Karantina, bulaşıcı hastalıkların yayılmasını önlemek için başvurulan etkin bir tedbirdir. Birey özgürlüğünü sınırlandırmasına rağmen çok haklı bir gerekçeye bağlı olarak uygulanmaktadır. İnsan güvenliği açısından devletlerin halk sağlığını koruma görevi bulunduğundan, gerektiğinde karantina gibi zorlayıcı ve zorunlu önlemlerin uygulanması gerekir. Alberto Giubilini, Thomas Douglas, Hannah Maslen and Julian Savulescu, "Quarantine, isolation and the duty of easy rescue in public health" (2018) (18) DWB 182, 184.

25 Rahmi Kılıç, Çiğdem Ataman Hatipoğlu ve Cemil Güneş, "Quarantine and its legal dimension” 2020 (50) Turkish Journal of Medical Sciences 544, 544.
} 
Bulaşıcı hastalıklara ilişkin karantina tedbirleri, hastalığın etkin olduğu ülke ya da bölgedeki ihtiyaca göre çeşitlilik gösterebilir. ${ }^{26}$

Bulaşıcı hastalıklarla mücadele edilirken, kısıtlamalara muhatap edilen toplumun temel haklarının da güvence altına alınması gerekir. ${ }^{27} \mathrm{Bu}$ nedenle bulaşıcı hastalıkla mücadele edilebilmesi adına alınan tedbirlerin etkin kullanılabilmesi için alınan tedbirlerin konusunun ve kapsamının açıkça tanımlanması gerekir. ${ }^{28}$

Suç genel teorisinde bazı hallerde, ceza normunu meydana getiren unsurlardan müeyyide kanun hükmünde belirlenmiş olmakta, ama fiil henüz belirlenmemiş olmaktadır. Açık ceza normu olarak ifade edilen bu hallerde müeyyide hükmü şimdiki halde mevcuttur, ama davranış hükmü gelecekte mevcut olacaktır. Burada normu koyan otoriteden, normu dolduran otorite farklıdır. Örneğin belirli bir konuda yetkili makamlar tarafından çıkarılacak özel ve genel nitelikteki emir veya tedbirlere uymamanın hükme bağlandığı hallerde olduğu gibi, norm gelecekteki bir unsurla tamamlanır. ${ }^{29}$ Madde 195 'de yer alan bulaşıcı hastalıklara ilişkin tedbirlere aykırı davranma suçunda, karantina altına almaya yönelik tedbirlerin ihlalinin suç olmasına rağmen tedbirlerin neler olduğu idarenin takdir yetkisine bırakılmıştır. Bu durumda md 195 hükmü, açık ceza normu olarak kabul edilmelidir. ${ }^{30} 5237$ sayılı Türk Ceza Kanunu md 2'de yer alan kanunilik ilkesine göre, suç teşkil eden haksızlığın, bu haksızlığın unsurlarının ve haksızlığın karşılığını oluşturan yaptırımların kanunla düzenlenmesi gerekir. Açık ceza normunun idarenin düzenleyici işlemleriyle gelecekte doldurulması, suç teşkil eden fiilin idare tarafından belirlenmesi sonucunu

\footnotetext{
26 Yaşar, Gökcan ve Artuç (n 8) 6037; Bulaşıcı hastalıklarla mücadele adına hangi tedbirlerin alınabileceği 1593 sayılı Umumi Hıfzıssıhha Kanunu md 72'de yer almaktadır. "Bulaşıcı hastalıklardan biri zuhur ettiği veya zuhurundan şüphelenildiği takdirde aşağıda gösterilen tedbirler tatbik olunur: a) Hasta olanların veya hasta olduğundan şüphe edilenlerin ve hastalı̆̆ neşrü tamim eylediği tetkikatı fenniye ile tebeyyün edenlerin fennen icap eden müddet zarfinda ve sihhat memurlarınca hanelerinde veva sihhi ve fenni șartları haiz mahallerde tecrit ve müșahede altına vaz'l. b) Hastalara veya hastalığa maruz bulunanlara serum veya aşı tatbiki. c) Eşhas, eşya, elbise, çamaşır ve binaların ve fennen intana maruz olduğu tebeyyün eden sair bilcümle mevaddın fenni tathiri. d) Hastalık neşreden haşarat ve hayvanatın itlafi. e) Memleket dahilinde seyahat eden eşhasın icap eden mahallerde muayenesi ve eşyalarının tathiri.f) Hastalı̆̆ın sirayet ve intişarına sebebiyet veren gıda maddelerinin sarf ve istihlakinin men'i. g) Dahilinde sari ve salgin hastallklardan biri zuhur eden umumi mahallerin tehlike zail oluncaya kadar set ve tahliyesi.",

27 Fidler (n 2) 79.

28 Gostin and Berkman (n 1) 147; bkz benzer görüș için Anayasa Mahkemesi. "5237 sayılı Kanun'un 2. maddesinde yer alan 'suçla ve cezada kanunilik' ilkesi uyarınca, hangi eylemlerin yasaklandığ l ve bu yasak eylemlere verilecek cezaların hiçbir kuşkuya yer bırakmayacak biçimde yasada gösterilmesi, kuralın açı, anlaşılır ve sınırlarının belli olması gerekmektedir. Kişilerin yasak eylemleri önceden bilmeleri düşüncesine dayanan bu ilkeyle temel hak ve özgürlüklerin güvence altına alınması amaçlanmaktadır. Bu ilke, aynı zamanda temel hak ve özgürlükleri en geniş biçimiyle gerçekleştirip güvence altına almakla yükümlü olan hukuk devletinin esas aldı̆̆ı değerlerden olup, uluslararası hukukta ve insan haklan belgelerinde de özel bir vere ve öneme sahip bulunmaktadır. Ceza yaptırımına bağlanan fiilin kanunun 'açıkça' suç sayması şartına bağlanmış olmasıyla, suç ve cezalara dair düzenlemelerin şekli bakımdan kanım biçiminde çıkarılmasl yeterli olmayıp, bunların içerik bakımından da belirli amacı gerçekleștirmeye elverişli olmaları gerekir. Bu açıdan kanunun metni, bireylerin hangi somut eylem ve olguya hangi hukuksal yaptırımın veya sonucun bağlandığını belirli bir açıllı ve kesinlikle öngörebilmelerine imkân verecek düzeyde kaleme alınmış olmalıdır. Bu nedenle belirli bir kesinlik içinde kanunda hangi eyleme hangi hukuksal yaptırımın bağlandığının bireyler tarafindan bilinmesi ve eylemlerin sonuçlarının öngörülebilmesi gerekir." (Anayasa Mahkemesi, 129/81, 24.05.2012).

29 Zeki Hafızoğulları, Ceza Normu: Normatif Bir Yapı Olarak Ceza Hukuku Düzeni (USA 1996) 280.

30 Hafizoğulları ve Özen (n 7) 128
} 
doğuracağından kanunilik ilkesine aykırıdır. ${ }^{31}$ Yetkili makamlar tarafından alınan tedbirler, bulaşıc1 hastalığın yapısı, türü, yaygınlığı gibi faktörlere göre belirlenmektedir. Bu durumda kanunilik ilkesine aykırı olarak suçun maddi konusu idarenin düzenleyici işlemleriyle kararlaştırılmaktadır. ${ }^{32}$ Bulaşıcı hastalıklara ilişkin tedbirlere aykırı davranma suçunda karantina altına almaya yönelik hangi tedbirlerin alınması gerekliliği idarenin yetkisindedir. Hastalıkla mücadele etmek adına gerekli olan önlemler, yetkili idari makamlar tarafindan 1593 sayılı Umumi Hifzıssıhha Kanunu hükümlerine atıf yapılarak alınmak zorundadır. Tedbirlerin neler olduğu md. 195'de yer almadığından md 195 hükmü açık ceza normu olarak ifade edilmektedir. Açık ceza normunda yaptırım belirlenmiştir; ancak kural, somut ve güncel bir biçimde normda yer almamaktadır ve içeriği (hareketten önce) idare tarafından doldurulmaktadır. Bulaşıcı hastalıklara ilişkin tedbirlere aykırı davranma suçunda, tedbirlerin somutlaştırılamamasının sebebi, salgının ne olduğunun, kapsamının ve etkisinin önceden tahmin edilebilmesinin mümkün olmamasıdır. Buna rağmen ceza kanunlarında hükmün açık bırakılması kanunilik ilkesine uygun değildir.$^{33}$ Kanunilik ilkesi ve onun alt unsurlarından belirlilik ilkesi gereği, çağdaş ceza hukukunda bu tür normlar tercih edilmemelidir.

Karantinanın amacı, hareket halinde olanlar arasında hastalığın görülme oranını ve etkilerini azaltmak, mevzuat, bilim, araştırmalar, hazırlık ve yapılacak planlar çerçevesinde hastalığın topluma girmesi, bulaşması ve yayılmasını önlemektir. ${ }^{34}$

Karantina tedbirleri, düzenleyici işlemler aracıllğıyla yerine getirildiği için suç, idarenin düzenleyici işlemine uyulmamasıdır. $\mathrm{Bu}$ nedenle düzenleyici işlemin hukuka uygun olmaması, sakat olması halinde alınan tedbirlere uymamak suç teşkil etmez. ${ }^{35}$

Bir bölgede bulaşıcı hastalığa bağlı olarak bir kişinin hastalanmış ya da ölmüş olmasına rağmen henüz yetkili makamlar tarafindan karantina tedbirleri alınmamışsa ya da alınmış olmasına rağmen henüz hastalık bir kişiye bulaşmamış ya da bir kişi

\footnotetext{
Abdullah Batuhan Baytaz, Kanunilik İlkesi Bağlamında Ceza ve Ceza Muhakemesi Hukukunda Yorum (Onikilevha 2018) 115 .

32 Önok (n 13) 157.

33 Bkz benzer görüş için Anayasa Mahkemesi. "5237 sayll Türk Ceza Kanunu'nun 297. maddesinin (1) numaralı fikrasında, infaz kurumuna veya tutukevine silah, uyuşturucu veya uyarıcı madde veya elektronik haberleşme aracı sokmak veya bulundurmak yasaklanmış ve bu yasağa uymayanların hapis cezası ile cezalandırılacakları öngörülmüştür. İtiraz konusu kuralın yer aldı̆̆ anılan maddenin (2) numaralı fikrasında ise (1) numaralı fikrada saylanların dışında kalıp da yetkili makamlar tarafindan infaz kurumuna veya tutukevine sokulması yasaklanmış bulunan eşyayl, bu yasağı bilerek, infaz kurumuna veya tutukevine sokan veya bulunduran ya da kullanan kişinin hapis cezast ile cezalandırllacağ belirtilmiştir. 297. maddenin (1) numaralı fikrasında suça konu olabilecek eşyaların nitelikleri tek tek sayılmış olmasına karşın, itiraz konusu kuralda böyle bir nitelik belirlemesi yapılmadan, sınırsız, belirsiz ve geniş bir alanda idare içinde yer alan yetkili makama suça konu olabilecek eşyaları belirleme yetkisi tanınmıştır. Buna göre kuralda, idare içinde yer alan yetkili makama suça konu olabilecek eșyaları belirlerken hangi nitelikleri esas alacağı hususuna açı ve belirgin olarak yer verilmediğinden dolayı kural, belirli ve öngörülebilir olmadı̆̆ı gibi suçun yasallı̆̆ı ilkesine de uygun değildir." (Anayasa Mahkemesi, 69/116, 21.10.2011).

34 Giubilini, Douglas, Maslen and Savulescu (n 24) 183.

35 Hafızoğulları ve Özen (n 7) 128.
} 
ölmemişse, o bölgede alınan tedbirlerin ihlali halinde, bulaşıcı hastalıklara ilişkin tedbirlere aykırı davranma suçu oluşmaz. ${ }^{36}$

Madde 195 'e göre karantina tedbirleri yalnızca bulaşıcı hastalığa yakalanmış ya da hastalıktan dolayı ölmüş olan kişinin bulunduğu yerde uygulanan önlemlerdir. Mevcut tedbirlere aykırı davranışların sınırlı bir alanda suç oluşturduğu anlaşılmaktadır. ${ }^{37}$ Virüse bağlı vakaların tüm ülkeye yayılması söz konusu olduğunda alınan tedbirlerin de tüm ülke genelinde geçerli olarak uygulanması gerekir. Bu durumda md 195' de yer alan "hastalığa yakalanmış ya da hastalıktan dolayı ölmüş kişinin bulunduğu yer" ifadesinin tüm ülke olarak yorumlanabilmesi gerekir. ${ }^{38}$

Bulaşıcı hastalıklara ilişkin tedbirlere aykırı davranma suçunda yer alan düzenleme, kapsam itibariyle mevcut COVID-19 virüsünden kaynaklanan salgınla mücadele adına ve kamunun sağlığını koruma adına yetersiz kalmaktadır. Salgınla birlikte ortaya çıkan ve cezalandırma faaliyetine dahil edilmesi gerekli olan fiil tipi, salgınla ilgili olarak idarece alınan tedbirlere uymama şeklinde ortaya çıkmaktadır. Oysa kanunda yer aldığı üzere fiilin suç oluşturmasının koşulu, bulaşıcı hastalıklardan birine yakalanan veya bu hastalıklardan ölmüş bir kişinin bulunduğu yerin karantina altına alınmasına dair yetkili makamlarca alınan tedbirlere uyulmaması olarak ifade edilmektedir. Bu açıdan bakıldığında kapsamı oldukça dar düzenlendiği için hüküm, mevcut salgınla ortaya çıkan hukuki ihtiyaçların gerisinde kalmaktadır. Ülke içerisinde henüz virüs vakası yaşanmamış olduğunda dahi idari makamlar tarafından tedbir amaçlı karantina uygulamasına gidilebilmesi mümkündür. Bu halde karantina tedbirlerine uyulmaması, md 195 gereğince bulaşıcı hastalıklara ilişkin tedbirlere aykırı davranma suçunu oluşturmamaktadır. Kanun hükmünün virüsle mücadele adına işlevsel hale getirilebilmesi için kanunda yer alan "bulaşıcı hastalıklardan birine yakalanmış veya bu hastalıklardan ölmüş kimsenin bulunduğu yer” koşulunun kanundan çıkartılması gerekmektedir. Diğer ifadeyle tedbirlerin alındığı yerin neresi olduğunun kanunda yer almaması gerekir.

Yetkili makamlarca yapılan tavsiye niteliğindeki uyarıların ihlal edilmesi md 195 gereğince sorumluluğa neden olmamaktadır. Alınan tedbirlere uyulmasının zorunlu tutulması gerekir.

Bulaşıcı hastalıkla mücadele adına alınması gereken karantina tedbirlerinin, yetkili makamlar tarafından alınması gerekir. Aksi halde maddi unsur eksikliğine bağlı olarak suç oluşmaz. ${ }^{39}$ Karantina tedbirlerini almaya yetkili makamlar 1593 sayılı Umumi Hıfzıssıhha Kanunu md 69'da düzenlenmiştir. "Sari ve salgın bir

\footnotetext{
Kangal (n 10) 438.

7 Şahbaz (n 3) 2263.

38 Bkz aksi görüș için. Bulașıcı hastalığa yakalanmış ve hastalıktan dolayı ölmüș olan kișinin bulunduğu yerin dar yorumlanması gerekir. Önok (n 13) 164.

39 Yaşar, Gökcan ve Artuç (n 8) 6037.
} 
hastalı̆̆ı vukuu tahakkuk eylediği takdirde sihhat memurları derakap lazım gelen tedbirlerin ittihazına ve bütün idari makamlar bu tedbirlerin tatbik ve icrasl hususunda muavenete mecburdurlar." Sihhat memurları, tedbirlerin neler olduğunu ve kapsamını belirleme konusunda yetkilidirler. Sıhhat memurlarının kimler olduğu ise 1593 say1lı Kanun md 303'de düzenlenmiştir. "Bu kanunda zikredilen slhhat memurlarl; Devlet, belediye ve idarei hususiye işlerinde kullanılan tabipler ve Sihhat ve İ̧̧timai Muavenet Vekaletinin lüzum göreceği ve mezuniyet vereceği hususlarda tabiplerin maiyetinde bulunan kü̧̧ük shhhat memurlarıdır. "’0

Son olarak, idari makamlar tarafindan alınan karantina tedbirlerinin topluma duyurulması gerekir. ${ }^{41}$ Bulaşıcı hastalığın yerel veya ülkeler arası olup olmadığına bakılmaksızın yetkili makamların aldığı tedbirlere uyulması zorunludur. Alınan önlemlere uyulması gerekliliği elverişli araçlarla topluma duyurulmalıdır. Tedbirlerin, gerek yazılı ve görsel medya gerekse sosyal medya aracılığıyla da paylaşılabilmesi mümkündür.

\section{Fail, Mağdur ve Konu}

Bulaşıcı hastalıklara ilişkin tedbirlere aykırı davranma suçunda, bulaşıcı hastalıklardan birine yakalanmış veya bu hastalıklardan ölmüş kimsenin bulunduğu yerin karantina altına alınmasıyla ilgili alınan tedbirlere aykırılık hali yaptırıma bağlanmaktadır.

Fail bakımından özel bir nitelik aranmadığından suçun faili herkes olabilir. ${ }^{42}$ Fail, bulaşıcı hastalıklara ilişkin tedbirlere aykırı davranan kişidir. ${ }^{43}$ Örneğin olası bir karantina önlemi esnasında karantina altına alınmış alandan kaçmaya çalışan veya karantinada olan bir kişiyle karantina önlemlerine aykırı bir biçimde temas kurmaya çalışan kişi, suçun failidir. ${ }^{44}$

Bulaşıcı hastalığın yayılması riskini engelleme amacıyla, karantina kapsamında alınan tedbirlerin sadece belirli bölgeler veya zaman dilimleri ya da belirli mekanlar, meslekler veya bazı yaş grupları için uygulanması mümkündür. Bu durumda bulaşıcı hastalıklara ilişkin tedbirlere aykııı davranma suçunun faili ancak bu kişiler olabilir.

\footnotetext{
Önok (n 13) 169.

41 Şahbaz (n 3) 2264.

42 Yaşar, Gökcan ve Artuç (n 8) 6036; Karantina altında bulunanlar dışında, tedbiri uygulayanlar olarak kolluk kuvvetlerinin ya da sağlık çalışanlarının da suçu işleme ihtimali bulunmaktadır. Örneğin hakkında karantina kararı alınan kişinin karantina alanına götürülmemesi ya da karantina alanına götürülürken yetkili makamın izni olmaksızın hastalığın yayılmasına yönelik tedbire aykırı şekilde başka bir yere götürülmesi de bulaşıı hastalıklara ilişkin tedbirlere aykırı davranma suçunun tanımına uymaktadır. İlave olarak 5237 sayılı Kanun md 266 hükmü gereğince görevi gereği olarak, elinde bulundurduğu araç ve gereçleri bulaşıcı hastalıklara ilişkin tedbirlere aykırı davranma suçunun işlenmesi sırasında kullanan kamu görevlisi hakkında md 195'den dolayı verilecek ceza artırılır. Kangal (n 10) 436.

43 Gerçeker (n 13) 1837.

44 Hafizoğulları ve Özen (n 7) 128.
} 
Bulaşıcı hastalıklara ilişkin tedbirlere aykırı davranma suçu belli kimselere karşı işlenmediği için tedbirlerin ihlal edilmesine bağlı olarak toplumda yaşayan herkesin zarar görme ihtimali bulunmakta, kamunun sağlığı tehdit edilmektedir. ${ }^{45}$ Tedbirlerin ihlal edilmesinin sonucunda bulaşıcı hastalık toplumu oluşturan bireylere bulaşmaktadır. Eğitim, sosyal ve ekonomik hayat bu durumdan olumsuz etkilenmektedir. Bu nedenle suçun mağduru, alınan tedbirlerle korunmak istenen toplumu oluşturan kişilerdir. ${ }^{46}$

Suç genel teorisinde suçun maddi konusu, tipik hareketinüzerinde gerçekleştirilmesi zorunlu olan şeydir. Maddi konu, suçu düzenleyen normda yer alan tanımda yer almaktadır. ${ }^{47}$ Bulaşıcı hastalıklara ilişkin tedbirlere aykırı davranma suçu, yerin karantina altına alınmasına dair yetkili makamlarca alınan tedbirlerin ihlal edilmesi halinde işlenebilir. $\mathrm{Bu}$ nedenle suçun maddi konusu, bulaşıcı hastalıklardan birine yakalanmış ya da ölmüş kimsenin bulunduğu yerin karantina altına alınmasına dair yetkili makamlarca alınan tedbirlerdir. ${ }^{48}$

Suç genel teorisinde suçun hukuki konusu, suç tarafından ihlal edilen hukuki varlık ya da menfaattir. ${ }^{49}$ Bulaşıcı hastalıklara ilişkin tedbirlere aykırı davranma suçuyla korunan hukuki yarar, toplum sağlığının korunması ve kamu düzeninin sağlanmasıdır. ${ }^{50}$ Esas olan hastalığın yayılmasının önüne geçmek ve her şeyden önce kamu sağlığını en üst güvenlik pozisyonunda tutmaktır. ${ }^{51}$ Suç tipi, hastalığa yakalanmış kişileri değil, hastalığın bulunduğu yer ile bir şekilde temasta bulunan kişileri korumaya yönelik düzenlenmiştir. Böylece kamu sağlığının korunması amacı güdülmektedir. ${ }^{52}$ Kamu menfaati bireylerin menfaatinden üstün tutulmuştur. İlave olarak tedbirlere uymayarak salgının artmasına neden olan kişiler, toplumda yer alan kişilerin hareket etme özgürlügünü de kısıtlamaktadırlar. Bu durum birey özgürlüğüne de zarar vermektedirler.

\footnotetext{
45 Yaşar, Gökcan ve Artuç (n 8) 6036.

46 Arslan ve Azizağaoğlu (n 13) 818; bkz aksi görüş için. Suçun mağduru toplum olmayıp, aldığı tedbirlere uyulmayan kamu idaresidir. Hafızoğulları ve Özen (n 7) 128.

47 Nevzat Toroslu ve Haluk Toroslu, Ceza Hukuku Genel Hükümler (Savaş 2019) 110.

48 Bayzit (n 18) 877.

49 Toroslu ve Toroslu (n 47) 109.

50 Çakmut (n 3) 545; Bulaşıcı hastalıklara ilişkin tedbirlere aykırı davranma suçunda korunan hukuki yararın, 765 sayı1ı Kanun ile 5237 sayılı Kanunda düzenlendiği yerlere ilişkin sistematik yorum yapıldığında, farklı olduğu görülmektedir. 765 sayılı Kanunda Devlet İdaresi Aleyhine Suçlar altında düzenlendiği için suçla korunan hukuki yarar, yerine getirilmesi gereken kamu hizmetinden bireyin yararlanma hakkıdır. 5237 sayılı Kanunda ise Kamu Sağlığına Karşı Suçlar altında düzenlendiği için suçla korunan hukuki yarar kamu sağlı̆̆ıdır. Kangal (n 10) 434.

51 Yaşar, Gökcan ve Artuç (n 8) 6035; Bir suçun kamuya yönelik tehdit oluşturmasının temel sebebi, suçun, önceden belirlenmesi mümkün olmayan kişilerin hakkını tehlikeye atmasıdır. Toplumun, kendisine yönelik suç teşkil eden fiil ve hareketlerden korunmak amacıyla önlem alması da çoğu zaman mümkün olmamaktadır. Sahir Erman ve Çetin Özek, Ceza Hukuku Özel Bölüm - Kamunun Selametine Karşı İşlenen Suçlar (Dünya 1995) 174.

52 Gerçeker (n 13) 1836; Kamunun sağlığı, kanunun güvencesi altındadır. Kamu sağlı̆̆ının korunmasının ceza kanunun amaçlarından biri olduğu, 5237 sayılı Türk Ceza Kanunu md 1'de yer almaktadır.
} 
Bulaşıcı hastalıklara ilişkin tedbirlere aykırı davranma suçu, tehlike suçudur. Kanun koyucu madde metninde somut olarak bir tehlikenin varlığını aramamıştır. Suç tanımında belli bir tehlikeli davranışın icra edilmesi başlı başına ceza yaptırımının uygulanmasını gerektirdiğinden soyut tehlike suçudur. Somut olarak hastalığın bulaştırılmış olması gerekli olmasa da alınan tedbirlerin ihlali halinde toplumda yaşayan herkes için tehlikeli bir duruma neden olunmaktadır. ${ }^{53}$ Soyut tehlike suçlarının bazılarında tehlikenin ortaya çıkabilmesi için failin hareketinin elverişli olup olmadığına bakılmaktadır. Bu suçlara "elverişlilik suçları" veya "potansiyel tehlike suçları" denilmektedir. Bulaşıcı hastalıklara ilişkin tedbirlere aykırı davranma suçu da soyut tehlike suçlarından potansiyel tehlike suçu sayılmaktadır. ${ }^{54}$ Bu suçlarda tehlikeye uygunluğun somut olayda bulunup bulunmadığının hakim tarafindan değerlendirilmesi gerekmektedir. Bulaşıcı hastalıklara ilişkin tedbirlere aykırı davranma suçunda failin aykırılık teşkil eden hareketinin objektif değerlendirme yapılarak, tedbirleri engellemeye elverişli boyutta olduğunun tespit edilmesi gerekir.

\section{Fiil}

Suç genel teorisinde hareket, netice ve nedensellik ilişkisinden oluşan eylem, fiil olarak adlandırılmaktadır. ${ }^{55}$

Bulaşıcı hastalıklara ilişkin tedbirlere aykırı davranma suçunda hareket, yetkili makamlarca alınan tedbirlere aykırı davranmaktır. ${ }^{56}$ İlgili tedbirlerin ne şekilde ihlal edileceği 5237 sayılı Kanun md. 195'de yer almadığından, tedbirlere uyulmamasının nasıl olduğunun bir önemi yoktur. Her türlü hareketle işlenebileceğinden serbest hareketli suç tipidir. ${ }^{57}$

Yetkili makamlarca alınan tedbirlere aykırı hareketin icrai ya da ihmali olabilmesi mümkündür. ${ }^{58}$ Örneğin karantina bölgesine girmek veya çıkmak izin koşuluna bağlı olduğunda, karantina bölgesine izinsiz girmek ya da izinsiz bölgeden ayrılmak; karantina tedbiri bir evde uygulanmaktaysa, bu yükümlülüğe uyulmaması; ülkeye giriş yapan kişilerin belli yerlerde belli süre bekletilmeleri zorunluluğu bulunmasına rağmen idari makamın kararı olmadan bulunması gereken yerden ayrılma gibi

\footnotetext{
53 Yaşar, Gökcan ve Artuç (n 8) 6038; Tehlike suçları, soyut ve somut tehlike suçları olmak üzere ikiye ayrılmaktadır. Soyut tehlike suçunda, kanuni tanımda yer alan fiilin icra edilmesi yeterli olup suç konusu üzerinde gerçek bir tehlikenin mevcut olup olmadığ araştırılmaz. Somut tehlike suçunda ise fiilin icra edilmesinden sonra somut olarak bir tehlikenin meydana gelmesi gerekir. İzzet Özgenç, Türk Ceza Hukuku Genel Hükümler (Seçkin 2019) 221.

${ }^{4}$ Önok (n 13) 170; bkz benzer görüş için İtalyan Yargıtayı. Salgın suçundan dolayı kişinin sorumlu tutulabilmesi için hareketin türü önemli değildir; bir salgına neden olmak için uygun olması yeterlidir. (Cassasione, 48014, 26.11.2019).

55 Hamide Zafer, Ceza Hukuku Genel Hükümler (Beta 2019) 226.

56 Hafızoğulları ve Özen (n 7) 128; Yargıtay’a göre somut olayda hangi hareketlerin alınan tedbirlerin ihlali olduğunun hükümde açıkça yer alması gerekir. "Oluşa göre sanı̆̆ın hareketinin ne suretle alınan tedbire fiilen mümanaat teşkil ettiği kanuna müsteniden izah edilmeksizin bulaşıcı hastalıklara ilișkin tedbirlere aykırı davranma suçundan sorumluluğa gidilmesi yolsuzdur." (Yargitay 2 CD, 3469/2499, 05.04.1949).

57 Gerçeker (n 13) 1837; Yaşar, Gökcan ve Artuç (n 8) 6038; Özütürk (n 17) 1021.

58 Kangal (n 10) 441; bkz aksi görüş için. Alınan tedbirlerin ihlali ancak fiili ve icrai hareketle gerçekleştirilmelidir. Özütürk (n 17) 1021.
} 
aykırılıklar icrai hareketle suçun işlenmesi halleridir. Ülkeye giriş yapan kişilerin, belli yerlerde belli süre bekletilmeleri zorunluluğu bulunmasına rağmen belirlenmiş yerlere gitmemeleri ise ihmali hareketle bulaşıcı hastalıklara ilişkin tedbirlere aykırı davranma suçuna örnek olarak verilebilir.

Bir kişinin virüs taşıdığının tespit edildiği veya bundan şüphelenildiği takdirde, sağlık memurlarınca bu kişinin muayene edilmesi ve hastalığın sebeplerinin araştırılmasına ilişkin herhangi bir işleme muhalefet edilmesi, hekimlere veya sağlık çalışanlarına zorluk çıkarma halleri de alınan tedbirlerin ihlal edilmesi olarak kabul edilmelidir. ${ }^{59}$ Benzer şekilde özel laboratuvarın COVID-19 testi yaptıranların bilgilerini Sağlık Bakanlığı ve kamu kurumlarıyla paylaşmaması, virüs tahlili yaptıran insanlarla ilgili bilgileri yetkili kurumlardan gizlemesi, suç tipikliğine uygun olması koşuluyla karantina tedbirlerinin uygulanmasının ihlal edilmesi olarak kabul edilmelidir.

Bulaşıcı hastalıklara ilişkin tedbirlere aykırı davranma suçunda, hastalığın oluşturduğu ya da oluşturabileceği tehlikenin önlenmesi amaçlanmaktadır. Kanun koyucu, idarenin almış olduğu tedbirlere uyulmamasını, toplum açısından tehlikeli kabul etmektedir. Bu nedenle alınan tedbirlerin ihlal edilmesi halinde suç tamamlanmıştır. ${ }^{60}$ İhlalin bir zarara ya da zarar tehlikesine neden olması aranmadığı için hareket suçudur. ${ }^{61}$

Bulaşıcı hastalıklara ilişkin tedbirlere aykırı davranma suçunda alınan tedbirlere uyulmaması suçun tamamlanması için yeterlidir. Tedbirlere uymamak amaciyla cebir, şiddet veya tehdit kullanılmasına gerek yoktur. ${ }^{62}$

\section{Suçun Manevi Unsuru}

Bulaşıcı hastalıklara ilişkin tedbirlere aykırı davranma suçunun taksirli hali Kanunda yer almadığından suç ancak kasten işlenebilmektedir. ${ }^{63}$ Yetkili makamlar tarafından alınmış olan tedbirlere bilerek ve istenerek uyulmaması gerekir. ${ }^{64}$

\footnotetext{
59 Özütürk (n 17) 1021; Bu durum 1593 sayılı Umumi Hıfzıssıhha Kanunu md 284'te yer almaktadır. "Bulaşıcı hastalıklar hakkında tetkikatta bulunmağa salahiyettar memurlara muhalefet eden kimseler Türk Ceza Kanununun 195 inci maddesi mucibince cezalandırllır."

60 Hafızoğulları ve Özen (n 7) 128; Tedbirlere aykırı davranan kişinin, herhangi bir kimseye hastalık bulaştırıp bulaştırmadığına bakılmamaktadır. Tedbirlere uymadığı ve kamu sağlığını tehlikeye attığı gerekçesiyle cezalandırılabilecektir. Şahbaz (n 3) 2264; Tedbirlere uymayacağını beyan etmesi, bildirmesi ya da alınan tedbirlerin gereksiz, aşırı ya da uygun olmayacağı konusunda eleştirilerde bulunması halinde, bulaşıcı hastalıklara ilişkin tedbirlere aykırı davranma suçu oluşmaz. Suçun tamamlanması için alınan tedbirlere eylemli olarak fiilen uyulmaması gerekir. Malkoç (n 13) 3233.

${ }_{61}$ Yaşar, Gökcan ve Artuç (n 8) 6037; Sadece hareketin yapılmasının suçun tamamlanması için yeterli olduğu suçlara, hareket suçu denilmektedir. Bundan başka bir neticenin, bir zararın oluşması beklenmez. Toroslu ve Toroslu (n 47) 146.

62 Yaşar, Gökcan ve Artuç (n 8) 6038.

63 Gerçeker (n 13) 1838

64 Gözübüyük (n 6) 339 .
} 
Bulaşıcı hastalıklara ilişkin tedbirlere aykırı davranma suçu, olası kastla da işlenebilir. ${ }^{65}$ Suçun oluşması için failin, alınan tedbirleri bilerek ve isteyerek ihlal etmesi yeterlidir. Bu nedenle genel kastın varlığ suçu işlemesi gerekli değildir. ${ }^{66}$

\section{Hukuka Aykırılık}

Bulaşıcı hastalıklara ilişkin tedbirlere aykırı davranma suçunda, alınmış ve duyurulmuş tedbirlere aykırı davranma fiilinin hukuka aykırı olması gerekir. $\mathrm{Bu}$ nedenle suç tipine uygun düşen hukuka uygunluk nedenlerinin somut olayda bulunması halinde fiil suç teşkil etmez. ${ }^{67}$

Fiil, kanun hükmünün yerine getirilmesi suretiyle hukuka uygun olabilir. Karantina bölgesine, kanun hükmü gereğince girme yetkisine sahip olan kolluk ya da sağlik personelinin hareketi hukuka uygun kabul edilmelidir. Meşru savunma hükümleri ilgili suç tipinde uygulanmaz. Karantina tedbirlerinin alınması, kişinin hakkına yönelik olarak haksız bir saldırı olarak kabul edilmeyeceğinden kişinin tedbirlere uymaması meşru savunma sayılmaz. Benzer şekilde hakkın kullanılması ve ilgilinin rızası hukuka uygunluk nedenlerinin, bulaşıcı hastalıklara ilişkin alınan tedbirlere aykırı davranılması suç tipinde uygulanması mümkün olmaz. ${ }^{68}$

\section{Kusurluluk}

Kusuru etkileyen nedenler olan yaş küçüklüğü, sağır ve dilsizlik, geçici nedenler, alkol veya uyuşturucu madde etkisinde olma hallerinin bulaşıcı hastalıklara ilişkin tedbirlere aykırı davranma suçunda uygulanabilmesi mümkündür. ${ }^{69}$ İlave olarak failin içinde bulunduğu zor durum, imkânsızlık nedeniyle tedbirleri ihlal etmiş olması halinde zorunluluk halinden de faydalanabilmesi gerekir. ${ }^{70}$ Örneğin karantina bölgesinde oluşan sel baskını nedeniyle bölgenin dışına çıkılması halinde sorumluluğa gidilmez.

Yetkili makamlar tarafından alınan karantina tedbirlerinin uygulanması haksız fiil olmadığından, kişinin hiddetli veya şiddetli elem dolayısıyla tepki vererek alınan tedbirleri ihlal etmesi halinde haks1z tahrik hükümlerinden yararlanabilmesi mümkün olmaz.

\footnotetext{
Çakmut (n 3) 549.

66 Özütürk (n 17) 1021; Gerçeker (n 13) 1838; Yaşar, Gökcan ve Artuç (n 8) 6038; Kangal (n 10) 443.

${ }_{67}$ Çakmut (n 3) 548; bkz aksi görüş için. Suçun unsuru olan hukuka aykırılığı ortadan kaldıran nedenler olan hukuka uygunluk nedenleri, tüm suçlar için uygulanabilen genel nitelikli hükümlerdir. Somut olayda bulunması halinde fiil suç teşkil etmez. Ancak hukuka uygunluk nedenlerinin kapsamı ve konusuyla uyuşmadığından, bulaşıı hastalıklara ilişkin tedbirlere aykırı davranma suçunda hukuka uygunluk nedenlerinin dikkate alınması mümkün olmaz. Hafızoğulları ve Özen (n 7) 129; Arslan ve Azizağaoğlu (n 13) 819.

68 Kangal (n 10) 446.

69 ibid 443.

$70 \quad$ Hafızoğulları ve Özen (n 7) 129.
} 
Yetkili makamlar tarafindan alınan karantina tedbirlerini uygulamakla görevli kişi, tedbirleri uygularken keyfi hareket ettiğinde, görevlinin haksız uygulamalarına karşı tepki olarak, alınan tedbirlerin ihlal edilmesi halinde haksız tahrik indirimi uygulanmamalıdır. Haksız tahrikte tepkinin, haksız fiili gerçekleştiren kişiye yönelik olması gerekir. Görevlinin, aşırı, orantısız veya keyfi uygulamaları her ne kadar haksız fiile neden olsa da haksız tahrikten yararlanılabilmesi için tepkinin görevliye verilmesi gerekirdi. Oysa tepkinin, karantina altına almak amacıyla yetkili makamlarca alınan tedbirlere yönelik verilmesi halinde, tepki üçüncü kişiye verilmiş olacağından haksız tahrik hükümlerinden yararlanılabilmesi mümkün olmaz. ${ }^{71}$ Görevlinin haksız uygulamalarına karşı görevliye verilen tepki, md 265'de yer alan görevi yaptırmamak için direnme suçunu oluşturmamaktadır. Görevi yaptırmamak için direnme suçunda, engellenmeye çalışılan bir görevden bahsetmek için bu görevin hukukun çizdiği sınırlar içerisinde ifa ediliyor olması gerekir. Görevlinin aşırı, orantısız, keyfi uygulamaları görevin ifası olarak kabul edilemez. ${ }^{72}$ Örneğin karantina altında tutulma süresi dolmasına rağmen kişinin keyfi yere dışarı çıkmasına izin verilmemesi halinde görevin ifasından bahsedilemez. Haksız uygulamalar görevin ifas1 olarak kabul edilmeyeceğinden verilen tepki de görevi yaptırmamak için direnme suçunu oluşturmamaktadır. Görevlinin haksız uygulamalarına karşı görevliye verilen tepki, fiilin niteliğine göre hakaret ${ }^{73}$, tehdit, kasten yaralama ${ }^{74}$ veya kasten öldürme suçlarını oluşturabilir. Bu durumda sayılan suçlar, görevlinin haksız fiiline tepki olarak işleneceğinden, fail hakkında haksız tahrik hükümlerinin uygulanmasina bir engel yoktur.

Bulaşıı hastalıklara ilişkin tedbirlere aykııı davranma suçunda failin hatası ceza sorumluluğunu etkilemektedir. Kusuru etkileyen neden olan hata, 5237 sayılı Türk Ceza Kanunu md 30'da dört fikra halinde düzenlenmiştir. Birinci fikraya göre, suçun maddi unsurunda hata halinde failin kastı ortadan kalkmaktadır. Maddi unsur hatası, bulaşıcı hastalıklara ilişkin tedbirlere aykırı davranma suçunda söz konusu olabilir. Yetkili makamlar tarafından alınan tedbirler duyurulmamış ya da duyurulmuş olmasina rağmen içinde bulunduğu ortam gereğince kişi öğrenememiş ise tedbirlere aykırı hareket eden kişi, suçun maddi konusunda hata yaptı̆̆ için kastı oluşmaz. ${ }^{75}$ Benzer şekilde tedbirler duyurulmasına rağmen kişinin, karantina altına alınan

\footnotetext{
$71 \quad$ Bkz aksi görüş için. Yetkili makamlar tarafından alınan karantina tedbirlerini uygulamakla görevli kişinin aşırı, orantısız veya keyfi uygulamaları haksız fiile neden olacağından, bu duruma tepki olarak alınan tedbirlere uymayan kişi haksız tahrik indiriminden istifade edebilir. Kangal (n 10) 444.

72 Ramazan Keklik, "Görevi Yaptırmamak İçin Direnme Suçu” (2015) 19 (4) AHBVÜHFD 259, 278.

73 Bkz benzer görüş için Yargıtay. (Yargıtay 5 CD, 02.12.2014, 8093/12058).

74 Bkz benzer görüş için Yargıtay. (Yargitay 5 CD, 16.04.2014, 809/4286).

75 Kangal (n 10) 443; bkz aksi görüş için. Kişinin, yetkili makamların aldığı önlemleri bilmemesi hali 5237 sayılı Türk Ceza Kanunu md 30/1'e değil md 30/4'e göre değerlendirilmelidir. Dördüncü firka gereğince hatası kaçınılmaz ise cezalandırılmaz. 5237 sayılı Türk Ceza Kanunu md 4'e göre ceza kanunlarını bilmemek mazeret sayılmamasına rağmen kişinin içinde bulunduğu ortam nedeniyle tedbirleri öğrenme imkansızlığı yaşaması halinde diğer ifadeyle fiilin haksızlık oluşturduğu hususunda kaçınılmaz hataya düşülürse bu hatasından yararlanır ve sorumluluğuna gidilemez. Hafizoğulları ve Özen (n 7) 129.
} 
bölgenin sınırlarını yanlış değerlendirmesi halinde suçun maddi koşullarında hata (md 30/1) gereğince kastının ortadan kalktığı kabul edilmelidir. ${ }^{76}$ İkinci fikraya göre, suçun nitelikli hallerinin gerçekleştiği hususunda hataya düşen kişi, bu hatasından yararlanmaktadır. Bulaşıcı hastalıklara ilişkin tedbirlere aykırı davranma suçunda nitelikli hal bulunmadığından failin nitelikli hallerde hataya düşmesi mümkün olmaz. Üçüncü fikraya göre, ceza sorumluluğunu kaldıran veya azaltan nedenlere ait koşulların gerçekleştiği hususunda hata halinde, failin hatası kaçınılmaz ise bu hatasından yararlanır. Örneğin kanun hükmü gereğince karantina bölgesine girme ya da çıkma konusunda kendisinin yetkili olduğunu düşünen kamu görevlisinin hatası kaçınılmaz ise fiili, karantina tedbirlerinin ihlali sayılmaz, hatasından yararlanır. Dördüncü fikraya göre, fiilin haksızlık oluşturduğu hususunda kaçınılmaz hata halinde, failin hatası kaçınılmaz ise cezalandırılmaz. Örneğin köy yerinde ikamet eden yaşlı birisinin, karantina önlemlerini bilmesine rağmen tarlaya gitmesi, odun kesmeye gitmesi halinde, köyde yaşamın doğal gereklerini yerine getirdiği düşünülmelidir. Eyleminin haksızlık teşkil ettiğini bilmemesi kabul edilebilir bir hata olarak değerlendirilmelidir. Bu halde hatası kaçınılmaz sayılır ve sorumluluğu bulunmaz.

\section{Suçun Özel İşleniş Biçimleri}

\section{A. Suça Teşebbüs}

Kişi, işlemeyi kastettiği bir suçu elverişli hareketlerle doğrudan doğruya icraya başlayıp da elinde olmayan nedenlerle tamamlayamaz ise teşebbüsten dolayı sorumlu tutulur. Suçun tamamlanmamış olmasına rağmen failin teşebbüsten dolayı sorumlu tutulmasının sebebi, ortada bir zarar veya tehlikenin mevcut olmasıdır. ${ }^{77}$

5237 sayılı Kanun md 195 'de yer alan bulaşıcı hastalıklara ilişkin tedbirlere aykırı davranma suçunda fail, yetkili makamlar tarafından alınan tedbirlere aykırı davranmak için harekete geçip, elinde olmayan nedenlerle hareketini tamamlayamaz ise fiil teşebbüs aşamasında kalmış olur. ${ }^{78}$

Suç genel teorisinde hareket suçlarına sadece icra hareketlerinin tamamlanmaması şeklindeki teşebbüs söz konusu olabilir. Çünkü bu tür suçlarda hareket tamamlandığında suç da tamamlanmıştır. İcra hareketlerinin tamamlanmaması şeklindeki teşebbüsün mümkün olması için hareketin belli bir oluşum sürecine sahip

\footnotetext{
Kangal (n 10) 443.

77 Özgenç (n 53) 495.

78 Yaşar, Gökcan ve Artuç (n 8) 6038; Gerçeker (n 13) 1838; Kangal (n 10) 442; bkz aksi görüş için. Bulaşıcı hastalıklara ilişkin tedbirlere aykırı davranma suçu, alınan tedbirlerin ihlal edilmesi halinde tamamlanır. Zarar suçu olmadığından hareket ile netice birbirinden ayrılamaz, hareket kısımlara bölünemez ve suça teşebbüs olmaz. Hafızoğulları ve Özen (n 7) 129.
} 
bulunması ya da parçalara bölünebilir olması gerekir. ${ }^{79}$ Bulaşıcı hastalıklara ilişkin tedbirlere aykırı davranma suçu hareket suçudur. Hareketin tamamlanması için belli bir zamanın geçmesinin gerektiği hallerde örneğin karantina altında tutulduğu yurttan yetkililerden izin almadan ayrılmak isteyen kişi, bahçeye iner ve ana kapıya doğru koşarken kolluk görevlilerince yakalandığında suça teşebbüsten sorumlu olur.

Bulaşıcı hastalıklara ilişkin tedbirlere aykııı davranma suçu icrai ya da ihmali hareketle işlenebilir. Fiilin icrai hareketle gerçekleştirilmesi sırasında elinde olmayan nedenlerle fail, icra hareketlerini tamamlayamaz ya da netice meydana gelmez ise suça teşebbüsten sorumlu tutulur. Örneğin karantina önlemleri kapsamında konutundan ayrılma yasağı bulunmasına rağmen kişi bu yasağı ihlal ederek sokağa çımaya çalışırken kolluk görevlileri tarafından engellenirse ya da karantina uygulaması kapsamında yurtdışından gelenlerin belli süre tutulduğu yerlerden kişi, tedbir süresi dolmadan ayrılmaya çalıştığında yetkili kişiler bu duruma engel olursa, suç teşebbüs aşamasında kalmış olur. Fiilin ihmali hareketle gerçekleştirilmesi durumunda hareketsizliğin gerçekleşmesiyle birlikte suç tamamlanmış olur ve tamamlanmış suça teşebbüs olmaz. Örneğin iki gün içinde karantina bölgesine gitmesi ve belli süre orada kalması gereken kişi iki gün boyunca hareketsiz kalırsa bulaşıcı hastalıklara ilişkin tedbirlere aykırı davranma suçu tamamlanmış olur. İki gün boyunca ise hareketsiz kalma hakkı olduğundan suç oluşmaz. Görüldüğü gibi suçun teşebbüs aşamasında kalma ihtimali bulunmamaktadır.

Bulaşıcı hastalıklara ilişkin tedbirlere aykırı davranma suçunda gönüllü vazgeçme hükümleri uygulanabilir. ${ }^{80}$ Fail, suçun icra hareketlerinden gönüllü vazgeçer veya kendi çabalarıyla suçun tamamlanmasını veya neticenin geç̧ekleşmesini önlerse, teşebbüsten dolayı cezalandırılmaz; fakat tamam olan kısım esasen bir suç oluşturduğu takdirde, sadece o suça ait ceza ile cezalandırılır (TCK md 36). Örneğin karantina altında tutulduğu yerden ayrılmak isteyen kişi, yetkili görevlileri yaralayarak hareketini gerçekleştirmek üzereyken vazgeçmiş olduğunda bulaşıcı hastalıklara ilişkin tedbirlere aykırı davranma suçuna teşebbüsten sorumlu olmaz ancak kasten yaralama suçundan sorumlu olur.

Etkin pişmanlık, suçun tamamlanmasından sonra ortaya çıkan ve suçun zararlı veya tehlikeli etkilerini ortadan kaldırmak veya hafifletmek için aktif bir çaba içine girmesiyle cezayı azaltan veya ortadan kaldıran bir kurumdur. ${ }^{81}$ Failin etkin pişmanlık hükümlerinden yararlanabilmesi için kanunda bunun açıç̧a öngörülmesi gerekir. Bulaşıcı hastalıklara ilişkin tedbirlere aykırı davranma suçuyla ilgili olarak md 195 'de etkin pişmanlığa yer verilmediğinden failin etkin pişmanlık hükümlerinden istifade edebilmesi mümkün olmaz.

\footnotetext{
Toroslu ve Toroslu (n 47) 314.

80 Kangal (n 10) 443.

81 Toroslu ve Toroslu (n 47) 311.
} 


\section{B. İştirak}

Bulaşıcı hastalıklara ilişkin tedbirlere aykırı davranma suçunun düzenlenmiş olduğu md 195 'de iştirake ilişkin özel düzenleme bulunmadığından suça iştirake ilişkin genel hükümler uygulanır. ${ }^{82}$ Alınmış olan tedbirleri failler birlikte ihlal etmiş olabilecekleri gibi biri, diğerinin fiiline fail ya da yardım eden olarak iştirak etmiş de olabilir. ${ }^{83}$

\section{C. İçtima}

Bulaşıcı hastalıklara ilişkin tedbirlere aykırı davranma suçu, tedbirlere ilişkin yükümlülüklere uyulmadığında tamamlanmış olur. Karantina tedbirlerine uymama sonucunda hastalığın bir başka kişiye bulaşması halinde, ihtimallere göre, 5237 sayılı Kanun md 86 vd maddelerde düzenlenen yaralama suçundan dolayı ayrıca sorumluluğa gidilebilmesi mümkündür. Bulaşıcı hastalıklara ilişkin tedbirlere aykırı davranma suçunun yanında kasten yaralama ve taksirle yaralama suçlarına ilişkin olarak gerçek içtima kuralları uygulanmalıdır. ${ }^{84}$ Tek fiil ile iki ayrı suçun işlenmesi durumunda, failin en ağır cezayı gerektiren suçtan sorumlu tutulduğu fikri içtima kuralı somut olayda uygulanamaz. Karantina tedbirleri ihlal edildikten sonra kasten veya taksirle yaralama suçları işlenmektedir. Somut olayda iki ayrı fiil bulunmaktadır. $\mathrm{Bu}$ nedenle gerçek içtima gereğince fail, hem bulaşıcı hastalıklara ilişkin tedbirlere aykırı davranma suçundan hem de kasten yaralama veya taksirle yaralama suçlarından sorumlu olmaktadır.

COVID-19 virüsü semptomlarının soğuk algınlığı gibi bir takım hastalıklarla benzerlik gösterdiği göz önüne alındığında öncelikle virüs taşıyan kişinin virüsü taşıdığını biliyor olması gerekir. Hasta olduğunu bilen kişi başka bir kişiye virüsü kasıtll bir şekilde bulaştırırsa kasten yaralama suçundan sorumlu olur. ${ }^{85}$ Virüs, hastalık bulaşan kişinin yaşamını tehlikeye sokan bir duruma neden olursa kasten yaralama suçundan verilecek ceza artırılır. Virüsün bulaştırılmasına bağlı olarak kişinin ölmesi halinde kasten öldürmeden dolayı sorumluluğa gidilmemelidir. COVID-19 virüs salgınına bağlı olarak hastaneye kaldırılan birçok kişinin uzunca bir tedavi sürecinden geçtiği dikkate alınarak yaralama sonucunda ölümün meydana geldiği düşünülmelidir. Bu nedenle virüsü kasıtlı olarak bulaştıran kişi, mağdur öldüğünde, neticesi sebebiyle ağırlaşan suç hükümlerine göre sorumlu tutulmalıdır. Ayrıca virüsün etkisinin failin hareketi sonucu ortaya çıktı̆̆ının ispatı oldukça güçtür. Ceza hukuku açısından nedensellik bağının tespitinin zorunlu olmasına

\footnotetext{
$82 \quad$ Arslan ve Azizağaoğlu (n 13) 819.

83 Çakmut (n 3) 551.

${ }^{84}$ Bkz benzer görüş için. Yaşar, Gökcan ve Artuç (n 8) 6039; bkz aksi görüş için. Karantina önlemlerini ihlal ederek, hastalık bir başka kişiye bulaştırılmışsa suçun niteliği değiştiğinden sadece kasten ya da taksirle yaralama suçundan dolayı sorumluluk doğmaktadır. Kangal (n 10) 447.

85 Bayzit (n 18) 889.
} 
karşın virüsün kimden geçtiğine yönelik takibin yapılması an itibariyle tıbben olanaksızdır. Dolayısıyla kişinin ilgili zaman aralığında virüs taşıyan başka kimseyle aynı ortamda bulunmadığ1 ve hatta paraya önceki günlerde dokunmuş olan kişilerin virüs taşımadığı tespit edilmeden kişinin sorumluluğuna gidilmesi mümkün değildir. Virüsü taşıdığını ve hasta olduğunu bilen kişi, başka bir insanı hasta etme kastıyla hareket etmemesine rağmen gerekli dikkat ve özeni göstermeyerek tedbirleri ihlal eder ve bir başka insanın hasta olmasına neden olursa taksirle yaralama suçundan sorumlu olur.

Bulaşıcı hastalıklara ilişkin tedbirlere aykırı davranma suçunda alınan tedbirlere uyulmaması suçun tamamlanması için yeterlidir. Tedbirlere uymamak amacıyla görevliye karşı cebir, şiddet veya tehdit kullanılmasına gerek yoktur. Cebir, şiddet ya da tehdit kullanılarak alınan tedbirler ihlal edildiğinde ise farklı neviden fikri içtima kuralının uygulanması gerekir. Bu durumda fail, md 195'de yer alan bulaşıcı hastalıklara ilişkin tedbirlere aykırı davranma suçundan değil cezası daha fazla olan md $265^{\prime} \mathrm{de}^{86}$ yer alan görevi yaptırmamak için direnme suçundan dolayı sorumlu tutulmalıdır. ${ }^{87}$ Görevi yaptırmamak için direnme suçunda mağdur olan görevlinin, kamu görevlisi olması gerekir. Yetkili makamlar tarafindan alınan karantina tedbirlerini uygulamakla görevli kişi, Devlet memuru olsun ya da olmasın 5237 sayılı Kanun md 6/1-c kapsamında kamusal faaliyete katıldığı için kamu görevlisi sayılmaktadır. Görevi yaptırmamak için direnme suçunun işlenmesi sırasında kasten yaralama suçunun neticesi sebebiyle ağırlaşmış hallerinin gerçekleşmesi durumunda, ayrıca kasten yaralama suçuna ilişkin hükümler uygulanır. (TCK md 265/5) Bu durumda gerçek içtima kuralının uygulanması gerekir. Tedbirlere uymamak amacıyla görevliye karşı uygulanan cebir, ağırlaştırılmış yaralamaya neden olduğunda fail, md 265'e göre görevi yaptırmamak için direnme suçu ve md 87'ye göre ağırlaştırılmış yaralama suçundan sorumlu olur.

5237 sayılı Kanun madde $195^{\prime}$ 'de yer alan bulaşıcı hastalıklara ilişkin tedbirlere aykırı davranma suçunda yer alan fiil, 5326 sayılı Kabahatler Kanunu md 32'de de Emre Aykırı Davranış başlığıyla yer almaktadır. ${ }^{88} \mathrm{Bu}$ durumda bulaşıcı hastalıklara ilişkin tedbirlere kişinin aykırı davranması halinde 5237 sayılı Kanun md 195'in yanında ayrıca Kabahatler Kanunu md 32'den dolayı sorumluluğun olup olmayacağının belirlenmesi gerekir. Bunun için Kabahatler Kanunu md 15/3'ün dikkate alınması gerekir. Bir fiil hem kabahat hem de suç olarak tanımlanmış

\footnotetext{
${ }_{86}$ Bkz “Kamu görevlisine karşı görevini yapmasını engellemek amactyla, cebir veya tehdit kullanan kişi, altı aydan üç yıla kadar hapis cezast ile cezalandırllır."

87 Yaşar, Gökcan ve Artuç (n 8) 6038; Kangal (n 10) 442; bkz aksi görüș için. Fiilin icrası sırasında yetkili kișilere cebir, șiddet ya da tehdidin gerçekleştirilmesi halinde 5237 sayılı Kanun md 265'de yer alan görevi yaptırmamak için direnme suçu da oluşabilir. Bu durumda gerçek içtima kuralı uygulanır. Parlar ve Hatipoğlu (n 13) 2931.

88 Bkz "Yetkili makamlar tarafindan adli iş̧lemler nedeniyle ya da kamu güvenliği, kamu düzeni veya genel săğlğın korunması amacıyla, hukuka uygun olarak verilen emre aykırı hareket eden kişiye yüz Türk Lirası idarî para cezası verilir. Bu cezaya emri veren makam tarafindan karar verilir."
} 
ise, sadece suçtan dolayı yaptırım uygulanabilir. Ancak, suçtan dolayı yaptırım uygulanamayan hallerde kabahat dolayısıyla yaptırım uygulanır. Bu nedenle aynı fiilden dolayı md 195'den dolayı sorumluluğuna gidilen kişinin, Kabahatler Kanunu md 32'den dolayı sorumluluğuna gidilemez. ${ }^{89}$

Bulaşıcı hastalıklara ilişkin tedbirlere aykırı davranma suçunda fail yetkili makamlarca alınan tedbirleri, mala zarar vermek suretiyle ihlal etmiş olabilir. Kişinin hareketi, mala zarar verme suçuna da neden olacağından farklı neviden fikri içtima gereğince cezası daha ağır olan 5237 sayılı Kanun md 152/1-a hükmü gereğince mala zarar verme suçundan sorumlu olur. ${ }^{90}$

Fail, aynı suçu işleme kararının icrası kapsamında olmak üzere bulaşıcı hastalıklara ilişkin tedbirlere birden fazla defa aykırı davranır ise zincirleme suç hükümleri uygulanabilir. ${ }^{91}$

\section{Yaptırım}

Bulaşıcı hastalıklara ilişkin tedbirlere aykırı davranma suçunun faili, iki aydan bir yıla kadar hapis cezası ile cezalandırılır.

Bulaşıcı hastalıklara ilişkin tedbirlere aykırı davranma suçunda, daha çok cezayı gerektiren nitelikli hal öngörülmemiştir. Benzer şekilde daha az cezayı gerektiren nitelikli hal de öngörülmemiş̧ir. Ancak 5237 sayllı Kanun md 62'de yer alan takdiri indirim hali bu suç tipi için de indirim nedeni olabilir. ${ }^{92}$

5237 sayılı Kanun md 50’ye göre kısa süreli hapis cezası, suçlunun kişiliğine, sosyal ve ekonomik durumuna, yargılama sürecinde duyduğu pişmanlığa ve suçun işlenmesindeki özelliklere göre seçenek yaptırımlara çevrilebilmektedir. Bulaşıcı hastalıklara ilişkin tedbirlere aykırı davranma suçunda hükmedilecek ceza, kısa süreli hapis cezası olduğunda seçenek yaptırımlara çevrilebilmektedir. ${ }^{93}$

\section{Soruşturma ve Kovuşturma}

Bulaşıcı hastalıklara ilişkin tedbirlere aykırı davranma suçu şikâyete tabi olmadığından dava zamanaşımı süresine riayet edilmek kaydıyla her zaman soruş̧urulabilir.

Dava zamanaşımı, suçun işlendiği tarihten itibaren belli bir süre geçtiği halde dava açılmamış veya dava açılmasına rağmen kanuni süre içinde sonuçlandırılmamış

\footnotetext{
Malkoç (n 13) 3233.

$90 \quad$ Kangal (n 10) 447.

91 Şahbaz (n 3) 2265.

92 Çakmut (n 3) 550.

93 ibid 551.
} 
ise ceza davasının düşmesi sonucunu doğuran bir ceza hukuku kurumudur. ${ }^{94}$ Beş yıldan fazla olmamak üzere hapis veya adlî para cezasını gerektiren suçlarda dava zamanaşımı süresi sekiz yıl olduğundan, bulaşıcı hastalıklara ilişkin tedbirlere aykırı davranma suçu için yapılan yargılamalarda dava zamanaşımı süresi suçun işlendiği tarihten itibaren sekiz yıl olarak uygulanmalıdır.

Bulaşıcı hastalıklara ilişkin tedbirlere aykırı davranma suçunun cezasının üst sınırı iki yılı aşmadığından, tutuklama tedbirinin uygulanması mümkün değildir. Alternatif koruma tedbiri olan adli kontrol tedbirinin uygulanması için ceza miktarı bulunmadığından, ilgili suçta adli kontrol tedbirine başvurmak olanaklıdır. Başvurulacak tedbir ile beklenen faydanın elde edilip edilemeyeceği iyi araştırılmalı ve muhakeme edilmelidir. Özellikle adli kontrol yükümlülükleri içerisinde yer alan konutunu terk etmeme önlemi, tedbirlerin daha etkili uygulanması bakımından faydalı olabilir.

5271 sayılı Ceza Muhakemesi Kanunu md 231/5'e göre sanığa yüklenen suçtan dolayı yapılan yargılama sonunda hükmolunan ceza, iki yıl veya daha az süreli hapis veya adli para cezası ise; mahkemece, hükmün açıklanmasının geri bırakılmasına karar verilebilir. Bulaşıcı hastalıklara ilişkin tedbirlere aykırı davranma suçu nedeniyle hükmedilecek hapis cezası iki yıl veya daha az hapis cezası olduğunda hükmün açıklanmasının geri bırakılması kararı verilmesi mümkündür. ${ }^{95}$

5237 sayılı Kanun md 51/1'e göre işlediği suçtan dolayı iki yıl veya daha az süreyle hapis cezasına mahkûm edilen kişinin cezası ertelenebilir. Bu sürenin üst sınırı, fiili işlediği sırada onsekiz yaşını doldurmamış veya altmışbeş yaşını bitirmiş olan kişiler bakımından üç yıldır. Bulaşıcı hastalıklara ilişkin tedbirlere aykırı davranma suçu nedeniyle hükmedilecek hapis cezası iki yıl veya altında olduğunda cezanın ertelenmesi mümkündür.

Uzlaştırma, suç isnadı altındaki şahıs ile suçun mağduru veya zarar göreni olan şahsın bir uzlaştırmacı aracılı̆̆ıyla iletişim kurarak anlaşmasıdır. Cinsel suçlar hariç olmak üzere uzlaşma yoluna ya şikayete tabi suçlarda ya da katalog olarak belirlenmiş olan suçlarda başvurulabilir. Bulaşıcı hastalıklara ilişkin tedbirlere aykırı davranma suçunun takibi şikayet tabi değildir; 5271 sayılı Kanun md 253/1-b'de yer alan katalog suçlar içerisinde de yer almadığından uzlaştırma yoluna gidilemez. ${ }^{96}$

5235 sayılı Adli Yarg1 İlk Derece Mahkemeleri ile Bölge Adliye Mahkemelerinin Kuruluş, Görev ve Yetkileri Hakkında Kanun md 8'e göre ceza mahkemeleri, Asliye ceza ve Ağır ceza mahkemeleri ile özel kanunlarla kurulan diğer ceza mahkemeleridir. Madde 12'ye göre suçun cezasının üst sınırı on yıldan fazla hapis cezalarını

\footnotetext{
94 Toroslu ve Toroslu (n 47) 495.

95 Yaşar, Gökcan ve Artuç (n 8) 6039.

96 Çakmut (n 3) 552.
} 
gerektiren suçlarla ilgili dava ve işler Ağır ceza mahkemesinin görevine girerken on yıl veya daha az hapis cezasını gerektiren dava ve işler Asliye ceza mahkemesinin görevine girmektedir. Bulaşıcı hastalıklara ilişkin tedbirlere aykırı davranma suçunun cezasının üst sınırı on yılı aşmadığından Asliye ceza mahkemesi görevlidir. Yetkili mahkeme ise bulaşıcı hastalıklara ilişkin tedbir kararının alındığı veya tedbirin fiilen uygulandığı yer değil, tedbir kararına aykırı davranılan yer mahkemesidir. ${ }^{97}$

5271 sayılı Kanun md 171/2'ye göre Cumhuriyet savcıs1, üst sınırı üç yıl veya daha az süreli hapis cezasını gerektiren suçlardan dolayı, yeterli şüphenin varlığına rağmen kamu davasının açılmasının ertelenmesine karar verebilir. Bulaşıcı hastalıklara ilişkin tedbirlere aykırı davranma suçunda hapis cezasının üst sınırı üç yılı aşmadığından kamu davasının açılmasının ertelenmesi kararı verilebilir.

5271 say1lı Kanun md 250/1'de katalog olarak belirtilen suçlarda soruşturma evresi sonunda kamu davasının açılmasının ertelenmesine karar verilmediği takdirde seri muhakeme usulü uygulanır. Bulaşıcı hastalıklara ilişkin tedbirlere aykırı davranma suçu, sayılan suçlar içerisinde yer almadığından seri muhakeme usulüne tabi değildir.

5271 sayılı Kanun md 251/1'e göre Asliye ceza mahkemesince, iddianamenin kabulünden sonra adli para cezasını ve/veya üst sınırı iki yıl veya daha az süreli hapis cezasını gerektiren suçlarda basit yargılama usulünün uygulanmasına karar verilebilmektedir. Bulaşıcı hastalıklara ilişkin tedbirlere aykırı davranma suçunda hapis cezasının üst sınırı iki yılı aşmadığından kovuşturma aşamasında basit yargılama usulü uygulanarak yargılama yapılabilir.

\section{Mukayeseli Hukuk Düzenlemesi}

İtalyan Ceza Kanunu'nda, karantina tedbirlerine uyulmaması ve bulaşıcı hastalıkların diğer kişilere bulaşmasına neden olunması halleri ayrı suç tiplerini oluşturmaktadır. Yetkili makamlar tarafından alınmış olan karantina önlemlerine aykırı hareket eden kişiler için md 650'ye göre üç aya kadar hapis veya para cezası uygulanmaktadır. Bulaşıcı hastalıkları kasten ya da ihmalkarlık göstererek bulaştırma halleri ceza kanununda ayrıca düzenlenmiştir. Salgın Suçu başlıklı md 438'e göre patojenik mikropların yayılması yoluyla salgına kasten neden olan herkes ömür boyu hapisle cezalandırılır. Eğer birkaç kişinin ölümü bu olaydan kaynaklanıyorsa, ölüm cezası uygulanır. (Ölüm cezası, ömür boyu hapis olarak infaz edilir) Bulaşıc1 hastalığı ihmalinden dolayı bulaştırma ise md 452'de Halk Sağlı̆̆ına Karşı İşlenen İhmal Suçu başlığıyla düzenlenmiştir. Suç tipi, md 438'de yer alan salgın suçuna atıf yapılarak oluşturulmuştur. ${ }^{98}$ Buna göre, ihmal göstererek, tedbirsiz ya da özensiz

\footnotetext{
Yaşar, Gökcan ve Artuç (n 8) 6039.

98 Nicola Canestrini, "COVID-19 Italian emergency legislation and infection of the rule of law" (2020) 11 (2) New Journal of European Criminal Law 116, 120.
} 
davranarak md 438'de yer alan salgın suçunun işlenmesine neden olan kişi, halk sağlığına karşı işlenen ihmal suçundan sorumlu olur. Madde 452'de yer alan halk sağlığına karşı işlenen ihmal suçunun cezası da yine md 438'de yer alan salgın suçuna atıf yapılarak belirlenmiştir. Salgın suçuna ilişkin hükümlerin ölüm cezasını oluşturduğu hallerde, halk sağlığına karşı işlenen ihmal suçunun cezası üç yıldan on iki yıla kadar hapis cezası; ömür boyu hapis cezası verilen durumlarda bir yıldan beş yıla hapis cezasıdır. ${ }^{99}$

Alman Ceza Kanunu'nda, bulaşıcı hastalıkların yayılmasını önlemek amacıyla alınan tedbirlerin ihlal edilmesine yönelik her hangi bir hüküm bulunmamaktadır. İlgili hükümler, özel ceza kanunu olan Enfeksiyondan Korunma Kanunu'nda yer almaktadır (IfSG). Bulaşıcı hastalıkların yayılmasını önlemek amacıyla alınmış olan karantina tedbirlerinin ihlali halinde, md 75/1'e göre iki yıla kadar hapis veya para cezas 1 verilebilmektedir. ${ }^{100}$

İsviçre Federal Halk Sağlığı Ofisi (FOPH), COVID-19 virüsünün İsviçre Ceza Kanunu'nun 231. maddesi anlamında "tehlikeli bir hastallk" olduğuna karar vermiştir. Bulaşıcı Hastalıkları Yayma başlığını taşıyan md 231'e göre tehlikeli bir bulaşıcı hastalığı kasıtlı olarak yayan herkes bir yıldan beş yıla kadar hapis cezas1 ile cezalandırılacaktır. Ayrıca COVID-19 virüsüyle mücadele etmek ve alınan karantina tedbirlerinin ihlal edilmesini engellemek amacıyla İsviçre Federal Konseyi, Koronavirüs ile Mücadele Önlemleri Hakkında Kararname oluşturmuştur. İlgili kararname md 10/f'ye göre, İsviçre Ceza Kanunu uyarınca daha ciddi bir suç olmadıkça, 6. madde kapsamındaki bulaşıcı hastalığın yayılmasının engellenmesine yönelik alınmış olan tedbirlere kasten karşı çıkan herkese üç yıla kadar hapis veya para cezas1 verilmektedir. ${ }^{101}$

Avusturya Ceza Kanunu md 178'e göre, bulaşıcı bir hastalığın insanlar arasında yayılmasına neden olabilecek bir davranışta bulunan herkes, üç yıla kadar hapis cezası ile cezalandırılır. Hareketlerin ihmali olarak gerçekleştirilmesi halinde ise bir yıla kadar hapis veya para cezası öngörülmektedir. ${ }^{102}$

Arjantin Ceza Kanunu, Kamu Güvenliğine Karşı Suçlar başlıklı yedinci bölüm md 205'e göre, salgının oluşmasını ya da yayılmasını engellemek amacıyla yetkili makamların almış olduğu her türlü önlemi ihlal eden kişilere, altı aydan iki yıla kadar hapis cezası uygulanmaktadır. ${ }^{103}$

\footnotetext{
Codice Penale Art 438 Epidemia; Art 452 Delitti colposi contro la salute pubblica.

100 Infektionsschutzgesetz - IfSG Art 75/1.

101 Ordinance on Measures to Combat the Coronavirus (COVID-19) Art $10 \mathrm{f}$.

102 Strafgesetzbuch Art 178 Vorsätzliche Gefährdung von Menschen durch übertragbare Krankheiten.

103 Codigo Penal de la Nacion Art 205 Delitos contra la salud pública.
} 
Fransa'da, bulaşıcı hastalıkla mücadele amacıyla bir dizi istisnai önlemden oluşan süreli Sağlık Acil Durum Kanunu bulunmaktadır. COVID-19 virüsünün neden olduğu sağlık krizine yanıt vermek için, salgın ile ilgili Acil Durum Kanunu, bölgenin tamamında veya bir kısmında acil bir durumun ilan edilmesini sağlamaktadır. Karantina tedbirlerini ihlal edenlere, sınırlama önlemlerinin daha etkili bir şekilde uygulanması için para cezası uygulanmaktadır. Sağlık Acil Durum Kanunu md 2'ye göre, karantina kapsamında alınan tedbirleri bir ayda dört kez ihlal edenlere ise para cezası ve altı aya kadar hapis cezası uygulanmaktadır. ${ }^{104}$

Çin Halk Cumhuriyeti Ceza Kanunu, Halk Sağlığına Karşı Tehlikeli Suçlar başlıklı beşinci bölüm md 330'a göre, Bulaşıcı Hastalıkların Önlenmesi ve Tedavisi Hakkında Kanun hükümlerine aykırı olarak, hükümde yer alan hareketlerden herhangi birini gerçekleştiren ve A sınıfı bulaşıcı bir hastalığın yayılmasına veya büyük bir yayılma riskine neden olan kişilere, üç yıldan fazla olmayan hapis cezası uygulanır. Sonuçların ciddi olması halinde, üç yıldan yedi yıla kadar hapis cezası uygulanır. A Sınıfı bulaşıcı hastalıkların aralığı, Bulaşıcı Hastalıkların Önlenmesi ve Tedavisi Hakkında Çin Halk Cumhuriyeti Kanunu'nun ilgili hükümlerine göre tanımlanır. ${ }^{105}$

\section{Sonuç}

Bulaşıcı hastalık, bir kaynaktan bir kişiye doğrudan ya da dolaylı olarak geçmesiyle oluşan toplumsal bir sağlık sorunudur. Bulaşıcı hastalıklar, toplumda büyük panik, kaygı ve salgınlara yol açabilmektedir. Bireylere yönelik olarak ölüm veya bedensel zararlarının yanında ekonomik anlamda da etkileri büyük olmaktadır. Bu nedenle bulaşıcı hastalıklarla mücadelede toplum sağlığının korunmasına ilişkin olarak yetkili idari organlar tarafından alınan tedbirler önem arz etmektedir. Alınan bu önlemler, mevcut hastalıkla mücadele adına hayati öneme sahip olduğundan herkes bu tedbirlere uymakla yükümlüdür.

2020 yılında ortaya çıkan COVID-19 virüsü, çok geniş bir alanda yayılan ve etkisini gösteren salgın hastalık olarak kabul edilmiştir. Virüs bulaşmış çoğu insan hafif ya da orta şiddette solunum hastalığı yaşamakta ve özel tedavi gerektirmeden iyileşmesine karşın yaşlı insanlar, diyabet, kronik solunum hastalığı ve kanser gibi rahatsızlığı olan insanlarda ölümcül etkisi kanıtlanmıştır. COVID-19 virüsü için geliştirilmiş aşı ya da kanıtlanmış bir tedavi yöntemi bulunmamakla birlikte potansiyel tedavileri değerlendiren birçok klinik çalışma yapılmaktadır.

Bulaşıcı hastalıkların kamu sağlığı açısından ciddi bir tehlike oluşturması itibariyle, birtakım tedbirlerin alınması noktasında kanuni düzenlemeler getirilmiştir. 1593 sayılı Umumi Hifzıssıhha Kanunu'nun 57 ve 96. maddeleri arasında bu tedbirlere

\footnotetext{
104 L'état D'urgence Sanitaire Art 2.

${ }_{105}$ Criminal Code of the People's Republic of China Art 330 Crimes of endangering public health.
} 
aykırı davrananlar düzenlenmiştir. 66. ve 67. maddelerde öngörülen hükümlere aykırı hareket edenlerin 5237 sayılı Türk Ceza Kanunu md 195'de yer alan Bulaşıcı Hastalıklara İlişkin Tedbirlere Aykırı Davranma suçundan dolayı cezalandırılacağı hüküm altına alınmıştır. Yetkili makamların almış olduğu önlemlere uyulması, insanların sağlığına tehlikeli hareket ve tepkilerden kaçınılması amacıyla tedbirlerin ihlal edilmesi yaptırıma bağlanmıştır.

Madde 195'de yer alan Bulaşıcı Hastalıklara İlişkin Tedbirlere Aykırı Davranma suçuyla korunan hukuksal değer kamu sağlının korunmasıdır. Bu amaçla, yetkili makamlarca alınan karantina tedbirlerine uymayan kişi cezalandırılmaktadır. Suçun faili, alınan tedbirlere aykırı hareket eden herkes olabilirken mağdur ise toplum içerisinde yaşayan herkestir.

İlgili suç tipinde öncelikli olarak mevcut bir bulaşıcı hastalığın varlığı koşulu aranmaktadır. Hastalığın bir kişiye bulaşmış ya da bir kişinin ölümüne neden olması gerekir. Bulaşıcı hastalıklardan birine yakalanmış veya bu hastalıklardan dolayı ölmüş kimsenin bulunduğu yerde bireylerin hareketinin kısıtlanmış olması diğer ifadeyle karantina önlemlerinin alınmış olması gerekir. Karantina önlemlerinin alınması için somut yer koşulunun aranması hükmün sınırlandırılmış olduğunu göstermektedir. Önlemler, mevzuatta yer alan makamlar tarafindan alınmalı ve toplum tarafindan uyulması zorunlu tutulmalıdır. Tavsiye niteliğindeki önlemlere aykırı hareket edilmesi suçun oluşmasına neden olmaz.

Yetkili makamlar tarafindan alınan tedbirlere aykırı hareket edilmesine yönelik olarak Kanunda özel hüküm bulunmadığından aktif ya da pasif hareketle suç işlenebilir. Karantina uygulamasına ve bu konuda alınmış olan tedbir ve kararlara uymayan kişiler cezalandırılmaktadır. Alınan tedbirlere aykırı hareket edilmesiyle birlikte suç tamamlanmış olur. Kanunda somut bir zarar veya tehlike koşulu aranmadığ 1 için ilgili suç tipi soyut tehlike suçu olarak kabul edilmektedir. Failin hareketi, karantina tedbirlerini ihlal etmeye elverişli olmalıdır. Bu nedenle md 195 hükmü, soyut tehlike suçlarından potansiyel tehlike suçu olarak kabul edilmektedir.

Ultima ratio ilkesine göre ceza hukukunun araçları en son çare olarak uygulanmalıdır. Bulaşıcı hastalıklara ilişkin tedbirlere aykırı davranma suçunda ultima ratio ilkesine uygun olarak kanun koyucu her ihlali cezalandırmamaktadır. Hastalığın bulunduğu yerin karantina altına alınmasına yönelik alınan tedbirlerin ihlali yaptırıma bağlanmaktadır. Hastalıkla mücadele etmek adına karantina dışındaki tedbirlere uyulmaması halinde idari yaptırımlar uygulanmaktadır.

Hastalığın bulunduğu yerin karantina altına alınmasına yönelik yetkili makamlar tarafından alınan tedbirlerin neler olduğu suç tipinde yer almamaktadır. Tedbirlerin neler olduğu konusunda idarenin takdir yetkisi bulunmaktadır. Bu nedenle md 
195'de yer alan suç tipi, açık ceza normudur. İdarenin düzenleyici işlemleriyle suç ihdas edilemez kuralı gereğince, suç tipinin içeriğinin idari makamlar tarafından doldurulması kanunilik ilkesine aykırılık olarak kabul edilmelidir.

Bulaşıcı hastalıklara ilişkin tedbirlere aykırı davranma suçu kasten işlenebilen suçlardandır. Failin hem hareketini hem de neticesini bilmesi ve istemesi gerekir. Hukuka uygunluk nedenlerinden kanun hükmünün yerine getirilmesi ilgili suç tipinde uygulanabilmektedir. Bu halde fail sorumlu olmaz. İlave olarak kusuru etkileyen hallerden zorunluluk hali ile failin hatası failin ceza sorumluluğunu etkilemektedir.

Bulaşıcı hastalıklara ilişkin tedbirlere aykırı davranma suçu aktif veya pasif hareketle işlenebilmektedir. Aktif hareketle işlendiğinde, hareketle netice arasında belli bir zaman aralığı varsa suça teşebbüs mümkündür. Suç pasif hareketle işlendiğinde ise hareketsiz kalınmasına bağlı olarak suç tamamlanmış olacağından md 195'de yer alan suça teşebbüs olmaz.

Bulaşıcı hastalığa yakalanmış olduğunu bilen kişinin, söz konusu hastalığı kasten başkasına bulaştırması halinde kasten yaralama suçundan sorumlu olur. Hastalı̆̆ın bulaştığı kişinin ölmesi halinde ise neticesi sebebiyle ağırlaşan suç hükümleri uygulanmalıdır. Bulaşıcı hastalığa yakalanmış olduğunu bilen kişinin, hastalığı kastı olmaksızın bulaştırması halinde ise taksirli suç hükümlerine göre sorumluluğuna gidilmelidir.

Bulaşıcı hastalıklara ilişkin tedbirlere aykırı davranma suçu şikayete tabi değildir. Suç tipinde, cezayı etkileyen nitelikli haller bulunmamaktadır. Fail, iki aydan bir yıla kadar hapis cezası ile cezalandırılmaktadır. Hükmedilecek ceza ertelenebilir. Kısa süreli hapis cezası olduğunda seçenek yaptırımlara çevrilebilmektedir.

Bulaşıcı hastalıklara ilişkin tedbirlere aykırı davranma suçunda görevli mahkeme, Asliye ceza mahkemesidir. Yetkili mahkeme ise tedbir kararına aykırı davranılan yer mahkemesidir. Dava zamanaşımı süresi suçun işlendiği tarihten itibaren sekiz yıl olarak uygulanmalıdır. Kamu davasının açılmasının ertelenmesine karar verebilir. Uzlaştırma hükümleri uygulanamaz. Tutuklama tedbirinin uygulanması mümkün olmamakla birlikte adli kontrol tedbirinin uygulanması olanaklıdır. Seri muhakeme usulüne tabi değildir. Kovuşturma aşamasında basit yargılama usulü uygulanarak yargılama yapılabilir. Hükmün açıklanmasının geri bırakılması kararı verilmesi mümkündür.

Bulaşıcı hastalıklara ilişkin tedbirlere aykırı davranma suçuna benzer düzenlemeler diğer ülke mevzuatlarında da bulunmaktadır. İtalyan Ceza Kanunu md 650, Alman Enfeksiyondan Korunma Kanunu md 75/1, Fransız Sağlik Acil Durum Kanunu md 2'ye göre, yetkili makamlar tarafından alınmış olan karantina önlemlerine aykırı hareket eden kişi cezalandırılmaktadır. İsviçre Koronavirüs 
İle Mücadele Önlemleri Hakkında Kararname md 10/f'ye göre, bulaşıcı hastalığın yayılmasının engellenmesine yönelik alınmış olan tedbirlere aykırılık cezalandırılmaktadır. Avusturya Ceza Kanunu md 178'e göre, bulaşıcı hastalığın insanlar arasında yayılmasına neden olmak yaptırıma bağlanmaktadır. Arjantin Ceza Kanunu md 205'e göre, yetkili makamların almış olduğu her türlü önlemi ihlal eden kişiler cezalandırılmaktadır. Çin Halk Cumhuriyeti Ceza Kanunu md 330'a göre, Bulaşıcı Hastalıkların Önlenmesi ve Tedavisi Hakkında Kanun hükümlerine aykırı hareket edenler cezalandırılmaktadır.

Hakem Değerlendirmesi: Dış bağımsız.

Çıkar Çatışması: Yazar çıkar çatışması bildirmemiştir.

Finansal Destek: Yazar bu çalışma için finansal destek almadığını beyan etmiştir.

Peer-review: Externally peer-reviewed.

Conflict of Interest: The author has no conflict of interest to declare.

Grant Support: The author declared that this study has received no financial support. 


\section{Bibliyografya/Bibliography}

Arslan Ç ve Azizağaoğlu B, Yeni Türk Ceza Kanunu Şerhi (Asil 2004).

Baytaz AB, Kanunilik İlkesi Bağlamında Ceza ve Ceza Muhakemesi Hukukunda Yorum (Onikilevha 2018).

Bayzit T, "Bulaşıcı Hastalıklara İlişkin Tedbirlere Aykırı Davranma Suçu” COVID-19 Salgınının Hukuki Boyutu (Editör Muhammet Özekes) (Onikilevha 2020) 865-898.

Canestrini N, "COVID-19 Italian emergency legislation and infection of the rule of law" (2020) 11 (2) New Journal of European Criminal Law 116-122.

Çakmut ÖY, "Bulaşıcı Hastalıklara İlişkin Tedbirlere Aykırı Davranma Suçu” Feridun Yenisey'e Armağan Cilt I (Beta 2014) 543 - 553.

Donay S, Türk Ceza Kanunu Şerhi (Beta 2007).

Erman S ve Özek Ç, Ceza Hukuku Özel Bölüm - Kamunun Selâmetine Karşı İşlenen Suçlar (TCK 369-413) (Dünya 1995).

Fidler DP, “Globalization, International Law, and Emerging Infectious Diseases” (1996) (2) EID 77 - 84.

Gerçeker H, Yorumlu ve Uygulamalı Türk Ceza Kanunu Cilt II (Seçkin 2020).

Giubilini A, Douglas T, Maslen H and Savulescu J, "Quarantine, isolation and the duty of easy rescue in public health" (2018) (18) DWB 182-189.

Gostin LO and Berkman BE, "Pandemic Influenza: Ethics, Law, and the Public's Health" (2007) ALR 121-175.

Gören S, Açıklamalı - İçtihatlı Türk Ceza Kanunu (2012).

Gözübüyük AP, Türk Ceza Kanunu Açılklaması, Cilt III (Sevinç 1970).

Hafızoğulları Z ve Özen M, Türk Ceza Hukuku Özel Hükümler Topluma Karşı Suçlar (USA 2017).

Hafızoğulları Z, Ceza Normu: Normatif Bir Yapı Olarak Ceza Hukuku Düzeni (USA 1996).

Kangal ZT, "Bulaşııı Hastalıklara İlişkin Tedbirlere Aykırı Davranma Suçu” Özel Ceza Hukuku CILT V (Onikilevha 2019) 433 - 450.

Keklik R, “Görevi Yaptırmamak İçin Direnme Suçu” (2015) 19 (4) AHBVÜHFD 259 - 296.

Kılıç R, Hatipoğlu ÇA ve Güneş C, "Quarantine and its legal dimension" (2020) (50) Turkish Journal of Medical Sciences 544-548.

Last JM, A Dictionary of Epidemolgy (Oxford University Press 2001).

Malkoç İ, Açıklamalı Türk Ceza Kanunu Cilt III (2013).

Önok RM, "Bulaşıcı Hastalıklara İlişkin Tedbirlere Aykırı Davranma Suçu (TCK md 195)" (2020) 9 (17) Anayasa Hukuku Dergisi 147-186.

Özgenç İ, Türk Ceza Hukuku Genel Hükümler (Seçkin 2019).

Özütürk N, Türk Ceza Kanunu Şerhi ve Açıklaması Cilt I (Filiz 1970).

Parlar A ve Hatipoğlu M, Türk Ceza Капипи Yоrитu (Seçkin 2008).

Savaş V ve Mollamahmutoğlu S, Türk Ceza Kanunu Yorumu Cilt II (Seçkin 1999).

Şahbaz İ, Açıklamalı ve İçtihatlı Türk Ceza Kanunu Cilt II (Yetkin 2016).

Tognotti E, "Lessons from the History of Quarantine, from Plague to Influenza A" (2013) 19 (2) EID $254-259$.

Toroslu N ve Toroslu H, Ceza Hukuku Genel Hükümler (Savaş 2019).

Yaşar O, Gökcan HT ve Artuç M, Yorumlu ve Uygulamalı Türk Ceza Kanunu Cilt IV (Adalet 2011).

Zafer H, Ceza Hukuku Genel Hükümler (Beta 2019). 
